\title{
Neuropathological Changes in Hydrocephalus-A Comprehensive Review
}

\author{
Domenico L. Di Curzio1,2 \\ ${ }^{1}$ Department of Medical Microbiology, University of Manitoba, Winnipeg, Canada \\ ${ }^{2}$ Department of Pathology, University of Manitoba, Children's Hospital Research Institute of Manitoba, Winnipeg, Canada \\ Email: umdicurd@myumanitoba.ca
}

How to cite this paper: Di Curzio, D.L. (2018) Neuropathological Changes in Hydrocephalus-A Comprehensive Review. Open Journal of Modern Neurosurgery, 8, 1-29. https://doi.org/10.4236/ojmn.2018.81001

Received: October 3, 2017

Accepted: December 9, 2017

Published: December 12, 2017

Copyright (c) 2018 by author and Scientific Research Publishing Inc. This work is licensed under the Creative Commons Attribution International License (CC BY 4.0).

http://creativecommons.org/licenses/by/4.0/

\section{(c) () Open Access}

\begin{abstract}
Hydrocephalus is a heterogeneous, neurological condition characterized by altered flow of cerebrospinal fluid (CSF) that can occur at any age. Neuropathological changes associated with hydrocephalus are dependent on the age of onset, rate of ventricular enlargement, and the etiology. Hydrocephalic brain damage is also influenced by contributions from both mechanical forces and metabolic changes, which increases the heterogeneity of the condition. However, as ventriculomegaly progresses, the surrounding brain tissue is compressed within the cranial vault, elevating intracranial pressure and eventually leading to severe brain damage. From this perspective, it makes sense that periventricular brain regions are the initial sites of damage as ventricular dilatation occurs. The following review of neuropathological changes in hydrocephalus will first discuss cellular and region specific damage from the ventricles and outward towards the cortex and brainstem. This will be followed by vascular and hypoxic changes associated with the condition. Both types of brain impairments are dependent on the severity of the condition, and they will be described accordingly.
\end{abstract}

\section{Keywords}

Hydrocephalus, Neuropathology, Brain, Vascular, Hypoxia

\section{Introduction}

Hydrocephalus is a heterogeneous, neurological condition that can occur at any age. The neuropathological consequences of hydrocephalus are dependent on the age of onset, rate of ventricular enlargement, and the etiology [1] [2] [3] [4]. Even gene expression has been shown to change in the hydrocephalic rat brain depending on the age of onset and duration of the condition [5]. Brain damage 
associated with the condition is also varied with contributions from both mechanical forces and metabolic changes that are difficult to distinguish [6]; however, as ventriculomegaly progresses, the surrounding brain tissue is compressed within the cranial vault, leading to increased intracranial pressure and eventually severe brain damage. From this perspective, it makes sense that periventricular brain regions/structures are the initial sites of damage as ventricular dilatation occurs. The following description of neuropathological changes in hydrocephalus will first discuss cellular and region specific damage from the ventricles and outward towards the cortex and brainstem. This will be followed by vascular and hypoxic changes associated with the condition. Both types of brain damage/impairment are dependent on the severity of the condition, particularly before therapeutic intervention commences.

\section{Structural, Regional, and Cellular Changes}

\subsection{Ependymal Layer}

The ependyma is a layer of cells that surrounds the ventricles of the brain and central canal of the spinal cord. These cells proliferate and differentiate during prenatal and early postnatal development with minimal proliferative activity in adult mammals, and they may have critical protective barrier functions during neural tube formation and neurodevelopment; however, their function in adult brains and response to injury are not well known [7] [8] [9] [10] [11]. When hydrocephalus occurs, it is possible for the ependymal layer to remain intact [12], but it is typically affected ranging from being stretched or torn [13] [14] to being completely abolished [10], which is referred to as ependymal denudation [15] [16] [17] that leaves only small collections of cells to line the ventricular wall [8] [18]. Animal models have shown that ependymal distortion and damage can commence by around 12 hours following CSF obstruction in the ventricles [19] [20] [21]. The different columnar and cuboidal ependymal cells can stretch but remain intact [22] [23], possibly as a protective mechanism, but this is limited by the severity of ventriculomegaly and rate at which expansion occurs [24]. Ependymal damage also ranges based on the brain regions it lies deep to, where ependyma overlaying the periventricular white matter at the dorsolateral angle and roof of the lateral ventricles [21] [25] and septum pellucidum [22] are the most severely affected. Such damage is subsequently followed by an inflammatory response with macrophages emerging on the ependymal surface [3] [26]. Several studies have shown an inability for ependymal cells to regenerate after hydrocephalus develops [17] or is induced [24] [27] [28], but there is evidence that increased mitotic activity of existing ependymal cells occurs after hydrocephalus induction [22]. Thus, ependyma damage occurs early after ventricular expansion, and it is not certain whether ependymal layer regrowth is possible, particularly as ventriculomegaly worsens.

\subsection{Subventricular Zone}

The brain region adjacent to the ependyma is the subependymal zone (SEZ) or 


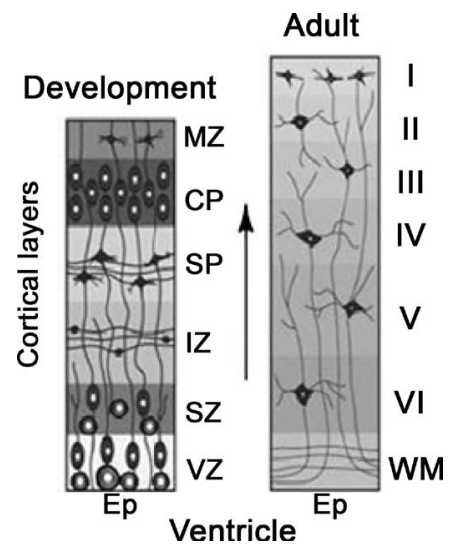

Figure 1. Cortical layering during development and adult cerebral cortex. $\mathrm{CP}-$ cortical plate; Ep-ependymal layer; IZ_-intermediate zone; MZ—marginal zone; SP-subplate; SZ-subventricular zone; VZ-ventricular zone; WM-white matter. Image adapted from Stiles \& Jernigan (2010). “The basics of brain development." Neuropsychol. Review, 20: 327-348, Figure 9b [262].

subventricular zone (SVZ) Figure 1. It is a thin area that persists from the embryonic germinal eminence (GE) that forms the lateral wall of the lateral ventricles, but it is virtually nonexistent over the third ventricle, cerebral aqueduct, and fourth ventricle [29] [30]. It is the site of neurogenesis where cell proliferation of newly formed brain cells continues into adulthood and is continually sent to different areas of the brain, including neurons through the rostral migratory stream to the olfactory bulbs and in the dentate gyrus of the hippocampus, as well as glial cells to the corpus callosum and cerebral cortex [31]. It has a strictly controlled cytoarchitecture containing astrocytes, small blood vessels, and three types of neural stem cells (NSCs) including self-renewing pluripotent precursors, neuroblasts or neuronal progenitor cells (NPCs), and oligodendrocyte precursors (OPCs) that are spatially located in specific positions [30] [31] [32] [33]. In humans and experimental models of hydrocephalus, periventricular reactive gliosis occurs within and surrounding the SEZ/SVZ, which may involve either or both hyperplasia or hypertrophy of glial cells [8] [17] [19] [34]-[39]. Various studies have also shown changes in cell numbers and mitotic activity within this region associated with hydrocephalus, where some studies have shown increased cell quantity [28] and cell proliferation [22] [40]. More recent work tends to show appreciable thinning and disorganization of the SVZ, along with a substantial decrease in cell proliferation overall [35] [37] [41] [42] [43] [44], as well as impaired mitotic cell cycling and migration of germinal cells away from the SVZ [45] [46], which may be associated with aberrant expression of neurotrophic factors in the ventricular zone (VZ) [43] [47] [48]. These impairments could disrupt neuronal organization [49], but human fetuses with hydrocephalus often exhibit no abnormalities in the germinal matrix and cortical organization [6]. There is also an increase in oligodendrocyte [40] and activated cell death in the SVZ and periventricular regions [44], as well as a decrease in Olig2-positive cells that could be indicative of glial precursor or mature oligodendrocyte li- 
neage [35]. Overall, the SEZ/SVZ is an important proliferative brain region that seems to be affected greatly by ventricular expansion.

\subsection{Periventricular Axons and White Matter}

With hydrocephalus, primary destruction of periventricular axons and white matter occurs early after onset with ventricular expansion causing physical stretching and compression to eventual axonal destruction as brain damage progresses [4] [50]. In humans and animal models, severe hydrocephalus is associated with appreciable corpus callosum thinning and compression of periventricular and subcortical white matter [4] [6] [14] [17] [35] [40] [41] [51]-[56]. Callosal injury is caused primarily by stretching, but dorsal grooving of the corpus callosum can occur from impingement on the falx cerebri [57], and such damages can lead to hemispheric disconnection [58] [59]. Destruction of the corpus callosum and fimbria/fornix in rat and human brains produces myelin degradation products and correlates with motor and cognitive deficits [60], whereas callosal size in hydrocephalic patients showed no correlation to cognition [61]. Compared to adults with hydrocephalus, early-onset hydrocephalus tends to show more compression of periventricular regions surrounding the occipital horn of the lateral ventricles because their expansion is more pronounced early in life [62] [63]. Axonal injury and focal petechial hemorrhage can occur in acute hydrocephalus, particularly at the angles of the ventricles [6]. Axonal degeneration and damage are commonly reported in hydrocephalic brains [28] [35] [55] [56] [64] [65] [66], where axonal cytoskeletal damage occurs through a calcium-mediated activation of proteolytic enzymes [67], and varicose enlargements of damaged but intact axons that are immunoreactive for amyloid precursor protein can be observed shortly after the onset of hydrocephalus [6] [68]. Chronic hydrocephalus is also associated with a loss or disconnection of axons [68] [69] [70], and degenerative changes can occur in human corticospinal tracts and animal spinal cords [4] [6] [60] [65] [71] [72]. Myelin loss occurs secondarily to axonal damage and loss [3] [39] [73] [74] [75], which may be caused by periventricular white matter edema [56] [76] [77] or related to elevated CSF levels of pro-apoptotic factor soluble FasL [78], but these remain uncertain. Myelin deposition in the young rat, cat, and infant brain is delayed by hydrocephalus [40] [51] [79] [80] [81], and myelin turnover is increased in chronic hydrocephalus [60]. There is also increased oligodendrocyte and apoptotic cell death, as well as reactive astroglial and microglial changes and phagocytosis that occur in the white matter [3] [35] [40] [51] [52] [73] [82].

\subsection{Extracellular Spaces and Water Content}

In the periventricular region, human and animal studies have shown that the hydrocephalic brain is edematous in association with increased intracranial pressure [83] [84] [85]. Brain tissue water content is elevated as far as $3 \mathrm{~mm}$ from the ventricle surface in hydrocephalic animals [86] [87] [88] [89] [90]. 
Extracellular spaces in the brain and periventricular white matter have been histologically shown to be enlarged in humans [91] [92] and animals [56] [73] [93], but these have only been verified ultrastructurally to $200 \mu \mathrm{m}$ from the ventricular surface [13] [22] [55] [94]. Numerous researchers believe that increased extracellular spaces may serve as diffusional pathways for "displaced CSF" based on using tracer agents from the ventricles into periventricular parenchyma [95] [96] [97] [98], but this is not certain because the brain produces extracellular fluid that flows into CSF spaces [99]. Alternately, research with hydrocephalic mice [100] [101] and rats [102] found compression of extracellular spaces in the gray matter of the cortex, while humans showed increases [103] that are not present in the caudate nucleus [22] [23]. However, it should be noted that some changes might be artifactual in some of these studies based on tissue fixation methods. Meanwhile, studies with hydrocephalic humans [104] and animals [105] [106] [107] have also shown decreased water content in the whole brain, cortex, and/or gray matter. CSF outflow and clearance of metabolic waste products and neurotransmitters are decreased in the hydrocephalic brain, and these extracellular changes further disrupt the microenvironment, which could impede neuronal function [4] [8] [108] [109].

\subsection{Cerebral Cortex and Subcortical Regions}

The cerebral cortex and subcortical structures are also affected by hydrocephalus, particularly as ventriculomegaly becomes more severe, where cortical thinning and distention are prevalent, along with stretching of the septum pellucidum [17] [19] [110]. In young infants with ventricular enlargement, cortical thinning is most apparent in the occipital regions [3] [8], and some infants may develop polygyria due to intrasulcal cortical unfolding [6] [111]. The cortical subplate can be disrupted, which could lead to subtle developmental abnormalities [42] [112]. Ventricular expansion can lead to cortical compression, which could eventually cause destruction of deep layers of the cortex, focal cortical dysgenesis, and neuronal loss, particularly if the white matter is completely destroyed [3] [6] [8] [39] [51] [73] [113]-[118]. The infundibular recess of the hypothalamus is typically enlarged in hydrocephalic children [119] [120] [121]. It has also been documented that hydrocephalus could impair the functional organization of the brain in children, along with disrupted structural brain development [122]. In this regard, microgyria has been found in hydrocephalic humans [121], as well as impaired NPC proliferation and migration in some infants [49]. Severe hydrocephalus can eventually cause swollen dendrites and axons, a decrease in dendritic spines and branching or even elimination of neuronal dendrites in the cortex and hippocampus [123]-[128] corresponding to an accumulation or loss of synaptic vesicle proteins (such as synaptophysin) and a loss of synapses [40] [127] [129] [130] [131] [132] and atrophy of the cerebral cortex and basal ganglia [8] [51] [64] [92].

Histological changes in the cerebral cortex are subtle and have often been 
overlooked [3] [8], but neuronal pyknosis and degeneration have been found in children and adults with hydrocephalus [133] [134], as well as cytoplasmic vacuolization in the hippocampus [135]. Hydrocephalic animal models have identified similar findings, as well as shrunken and dark cell changes, swelling, cell loss, and membrane disruption of neurons in the cerebral cortex, hippocampus, septal area, caudate nucleus, thalamus, and hypothalamus [8] [56] [64] [119] [121] [136]-[143]. Chronic severe hydrocephalus is also associated with reactive astrogliosis in the cortex, as well as neurofibrillary tangles in cortical, hippocampal, and brainstem neurons [8] [114] [144]-[149]. Reactive changes can occur in neurons as well, which may be protective, including upregulation of bcl-2, growth-associated protein-43 (GAP-43), nerve growth factor, and other protective proteins [5] [150] [151] [152] [153]. Meanwhile, neurochemical changes in the septohippocampal system of hydrocephalic patients [154]-[159] and animals [160] [161] [162] [163] are associated with memory and learning impairments. However, one study found that memory dysfunction in hydrocephalic adults was associated with septohippocampal changes when it was due to aqueductal stenosis, whereas memory deficits in normal pressure hydrocephalus appeared related to prefrontal structural damage [164]. Hydrocephalus may also impair neuronal function by changing neural conduction along functional pathways [165]-[170], impeding long-term potentiation [127] [171], and decreasing the responsiveness or size of neurons in the visual cortex [138] [172]. Other damage has been documented along the visual pathway due the ventricular enlargement including damage to the geniculo-cortical pathway/optic radiations, distention of the pineal recess of the third ventricle leading to upward gaze palsy, or even ischemic damage due to compression of the posterior cerebral artery [169] [173] [174] [175] [176] [177]. Hydrocephalus is also associated with changes in the concentrations or function of different neurotransmitters, neuropeptides, and receptors [8] [157] [178]-[188], disrupting the clearance of various metabolites from the brain [108] [118] [189] [190], and inducing neuroendocrine disturbances by altering hormone production or secretion that may be due to distortions of the pituitary or hypothalamus [191]-[196].

\subsection{Cerebellum and Brainstem}

There are also neuropathological changes in the cerebellum and brainstem. The shape of the cerebellum is distorted in people with spina bifida and hydrocephalus [197]. Although the Chiari II malformation is associated with cerebellar, brainstem, and fourth ventricle deformities [17] [198] [199] where subsequent hydrocephalus often develops, this malformation likely occurs secondary to myelomeningocele instead of ventriculomegaly [200] [201]. There may be abnormal degeneration and stunted growth of the central lobes of the cerebellum, which seems to develop normally at first [202], which could be associated with ischemic changes [203] [204] [205]. There are also changes in neurotransmitter levels in the cerebellum of hydrocephalic animals [190] [206], as well as increas- 
es in reactive oxygen species after ventricular dilatation commences in the hydrocephalus Texas (H-Tx) rat [207], which may account for impaired cerebellar functioning observed in those with spina bifida [208]. Historically, a severely misshapen medulla oblongata was often reported in the literature [17], but such brainstem changes are not observed that often today, which are possibly due to early surgical intervention on affected individuals or increased abortions rates [4]. As mentioned previously, descending axons and white matter corticospinal tracts in the brainstem and spinal cord can be damaged as hydrocephalus progresses [4] [6] [60] [71], and neurofibrillary tangles can be observed in brainstem neurons with chronic severe hydrocephalus [8]. Thus, cerebellar and brainstem changes can occur with hydrocephalus, but more detailed investigations are necessary to determine more clearly how these brain structures are affected by this condition.

\section{Vascular and Oxidative Pathogenesis}

\subsection{Cerebral Blood Flow and Vascular Changes}

As the cerebral ventricles enlarge, tissue compression and axonal stretching and tearing occur, but hydrocephalus also adversely affects cerebral metabolism, cerebral blood vessels, and cerebral blood flow especially in the white matter [4] [8] [209] [210] [211] [212] [213]. In particular, white matter ischemia or hypoperfusion happens simultaneously to the tissue damage [50] [68] [214], and there is reduced cerebral blood flow, which is correlated with the size of the ventricles in infants [215] [216] [217] [218]. Adults with hydrocephalus also experience reduced cerebral blood flow, particularly in the frontal lobes [8] [219], and extended periods of elevated intracranial pressure above normal cerebral perfusion thresholds often lead to worse outcomes for young and older patients with the condition [220]. Animal studies also show reduced cerebral blood flow and ischemic changes with hydrocephalus, as well as changes in oxidative metabolism in the cortex and subcortical regions, including the hippocampus [79] [87] [207] [213] [221] [222] [223] [224], which are more prominent during early stages while ventricular enlargement is actively taking place [2] [88].

\subsection{Microvascular Changes}

Microvascular changes in hydrocephalus were first identified long ago by Penfield [134] who was apt to recognize that ventricular enlargement likely impeded the vascular supply to the brain. Later studies were able to show decreased density of capillaries in the corpus callosum of humans with hydrocephalus [52], as well as decreased number, caliber, and patency of capillaries in periventricular white and gray matter of experimental and mutant animal models of hydrocephalus [64] [117] [211] [225] [226] [227] [228]. Some of these studies suggested that capillary loss may be due to the combinatorial effect of increased CSF pressure and distortion of brain tissue, and reduced cerebral blood flow could result if this loss was extensive enough. When examining the endothelial cells of capil- 
laries in hydrocephalic human brains, they were found to have numerous pinocytotic vesicles [6] [229] [230] and enlarged extracellular spaces [231]. In experimental animal studies, some report a normal ultrastructure [56] [94], while others have observed edema of endothelial cell cytoplasm [137] and separations of endothelial tight junctions in periventricular white matter [226] [227], which might be associated with an alternate route for CSF absorption. Related to this, the blood-brain barrier ( $\mathrm{BBB}$ ) appears to remain intact with hydrocephalus, so the role of $\mathrm{BBB}$ alterations in hydrocephalus is unclear [50]. Indirectly, it is known that the composition of CSF [108] and extracellular fluid is altered in hydrocephalus [3]. In addition, the movement of water and extracellular tracers are restricted [106] [214] [232] [233], whereas water normally exchanges across the BBB relatively freely [234] [235] [236]. Other suggestive evidence of altered permeability of the BBB has been observed in hydrocephalic adult patients who display changes in the relative levels of CSF albumin and plasma-derived immunoglobulin G [237]. In addition, one study found that aquaporin 4, but not aquaporin 1 or 9 , expression was elevated in hydrocephalic rat brains, and it was postulated that this change might facilitate the efflux of water from the brain through astrocytes into the capillaries [238]. Meanwhile, another study showed that hydrocephalic rats exhibited only focal and perhaps transient increased opening of BBB permeability, which was speculated to relate mainly to mechanical disruption of small periventricular blood vessels rather than a generalized capillary phenomenon [239].

\subsection{Choroid Plexus}

The choroid plexus is a tight epithelium surrounding a vascularized stroma that is located within the roof of all four ventricles and produces most of the CSF in circulation. Because of its unique location, the choroid plexus is a circumventricular organ that forms one of the interfaces between the blood and the CSF, and it is important for contributing to brain homeostasis, where it is involved in various biochemical exchanges supplying or removing nutrients, peptides, hormones, metabolites, and waste [240]. In regards to its main function, CSF overproduction by the choroid plexus is a rare a cause of hydrocephalus [3] [8] [241]. Some studies of experimental hydrocephalus have reported a normal choroid plexus [24] [64] [242], whereas many others have described various alterations including distortion of microvilli, compression and vacuolization of choroidal cells, increased intracellular spaces and inclusions, and epithelial atrophy [26] [70] [243] [244] [245] [246]. In humans with chronic hydrocephalus, atrophy of the choroid plexus epithelium and stromal sclerosis have been observed [8] [17] [50] [92] [121]. Such changes have been suggested to be associated with reduced secretory functioning of the choroid plexus [34] [50] [247] [248] [249] [250]. In addition to the choroid plexus, other circumventricular organs have shown changes in hydrocephalic animals, such as increases in angiotensin II receptor content in circumventricular organs [251], the subcommissural organ that is de- 
creased in size [252] and exhibits decreased glycoprotein immunoreactivity [253], and the subfornical organ can become damaged as the condition progresses [254].

\section{Hypoxic, Oxidative, and Nitrosylative Changes}

Since hydrocephalus is associated with tissue compression, reduced cerebral blood flow, and periventricular white matter ischemia, studies have also shown that periventricular white matter undergoes hypoxic, oxidative, and nitrosylative changes [255]. In particular, pimonidazole hydrochloride, which forms adduct with thiol groups in proteins of hypoxic tissue [256], is detectable in periventricular capillaries and white matter glial cells [255]. Numerous studies have found that hydrocephalic rodent brains exhibit oxidation and lipid peroxidation, which proceeds oxygen free radical damage to cell membranes and is indicative of hypoxic and oxidative changes [36] [207] [255] [257] [258] [259] [260]. In the CSF of hydrocephalic children, various metabolites suggestive of hypoxic metabolism have also been detected [108] along with lipid peroxidation [261]. Some studies with $\mathrm{H}$-Tx rats found decreased intensity of histochemical staining of neurons for NADPH-diaphorase [139] and detected protein nitrosylation associated with oxidative stress [207]. Meanwhile, other studies found increased nitric oxide synthase (NOS) immunostaining [222] and elevated mRNA levels of a neuronal NOS inhibitor in hydrocephalic rats [5]. Lastly, nitrotyrosine has also been detected in periventricular white matter vessels along with increased nitric oxide production in the brains of hydrocephalic rats, which are suggestive of nitrosylative, hypoxic changes associated with the condition [255].

\section{Summary and Future Research Prospects}

Hydrocephalus is a neurological condition characterized by altered CSF flow leading to an accumulation of CSF inside the cranial vault. The neuropathological changes associated with hydrocephalus arise from both mechanical forces and metabolic changes, and they are heterogeneous due a variety of factors including the age of onset, rate of ventricular enlargement, and the etiology. Ventriculomegaly causes compression of brain tissue within the cranial vault, which increases intracranial pressure and leads to severe brain damage. In this review, hydrocephalic neuropathological changes have been described based on research with humans and animal models of the condition, which includes cellular and region specific damage, along with vascular and hypoxic changes. Overall, hydrocephalus can occur at any age from multiple causes and displays varied levels of severity, which is why neuropathological changes associated with the condition are highly heterogeneous. Despite the wealth of knowledge about the neuropathological changes associated with hydrocephalus, these changes are derived from multiple factors and are not completely understood. Moreover, there is currently no definitive cure for hydrocephalus, which is strongly associated with the multifactorial etiology and heterogeneity of the condition. Current strategies 
to treat hydrocephalus are primarily through surgical intervention by way of ventricular shunting and/or endoscopic third ventriculostomy, but these procedures are associated with both similar and unique complications. Nonsurgical pharmacological approaches for treatment are being extensively investigated through preclinical animal models of hydrocephalus. Though various therapeutic agents have potentially shown beneficial outcomes, they have mainly been tested in rodent models and are not necessarily curative on their own. Thus, future research should be focused on using gyrencephalic animal models to confirm the neuropathological changes observed in rodent models and establish credibility of therapeutic effects obtained in those studies to advance towards clinical trials with these pharmacological agents. There is also very little to no animal or clinical data on the synergistic effects of combined surgical and nonsurgical approaches in treating hydrocephalus. Thus, it is integral that future research is aimed towards examining drug agents that have shown promise for various aspects of brain protection in response to ventriculomegaly, and then administer them in conjunction with surgical interventions. Such attempts would ensure that a surgical procedure is performed to reduce mechanical pressure and ventricular enlargement associated with CSF buildup, while therapeutic agents would be aimed at reducing tissue or cellular damage. If more imaging, behavioral, tissue, and cellular data are collected using this dual approach and beneficial and lasting effects are observed, it is likely that this could progress towards more clinical trials and establish further understanding of the neuropathological changes associated with hydrocephalus.

\section{References}

[1] Hirayama, A. (1980) Histopathological Study of Congenital and Acquired Experimental Hydrocephalus. Brain \& Development, 2, 171-189. https://doi.org/10.1016/S0387-7604(80)80038-6

[2] Hochwald, G.M. (1985) Animal Models of Hydrocephalus: Recent Developments. Proceedings of the Society for Experimental Biology and Medicine, 178, 1-11. https://doi.org/10.3181/00379727-178-41977

[3] Del Bigio, M.R. (2001) Pathophysiologic Consequences of Hydrocephalus. Neurosurgery Clinics of North America, 12, 639-649.

[4] Del Bigio, M.R. (2010) Neuropathology and Structural Changes in Hydrocephalus. Developmental Disabilities Research Reviews, 16, 16-22. https://doi.org/10.1002/ddrr.94

[5] Balasubramaniam, J. and Del Bigio, M.R. (2002) Analysis of Age-Dependant Alteration in the Brain Gene Expression Profile Following Induction of Hydrocephalus in Rats. Experimental Neurology, 173, 105-113. https://doi.org/10.1006/exnr.2001.7831

[6] Del Bigio, M.R. (2004) Cellular Damage and Prevention in Childhood Hydrocephalus. Brain Pathology, 14, 317-324. https://doi.org/10.1111/j.1750-3639.2004.tb00071.x

[7] Bruni, J.E., Del Bigio, M.R. and Clattenburg, R.E. (1985) Ependyma: Normal and Pathological. A Review of the Literature. Brain Research, 356, 1-19. 
https://doi.org/10.1016/0165-0173(85)90016-5

[8] Del Bigio, M.R. (1993) Neuropathological Changes Caused by Hydrocephalus. Acta Neuropathologica, 85, 573-585. https://doi.org/10.1007/BF00334666

[9] Del Bigio, M.R. (1995) The Ependyma: A Protective Barrier between Brain and Cerebrospinal Fluid. Glia, 14, 1-13. https://doi.org/10.1002/glia.440140102

[10] Del Bigio, M.R. (2010b) Ependymal Cells: Biology and Pathology. Acta Neuropathologica, 119, 55-73. https://doi.org/10.1007/s00401-009-0624-y

[11] Sarnat, H.B. (1995) Ependymal Reactions to Injury. A Review. Journal of Neuropathology \& Experimental Neurology, 54, 1-15. https://doi.org/10.1097/00005072-199501000-00001

[12] Bannister, C.M. and Mundy, J.E. (1979) Some Scanning Electron Microscopic Observations of the Ependymal Surface of Hydrocephalic Hy 3 Mice and a Human Infant. Acta Neurochirurgica (Wien), 46, 159-168. https://doi.org/10.1007/BF01407689

[13] Del Bigio, M.R., Bruni, J.E. and Fewer, H.D. (1985) Human Neonatal Hydrocephalus. An Electron Microscopic Study of the Periventricular Tissue. Journal of Neurosurgery, 63, 56-63. https://doi.org/10.3171/jns.1985.63.1.0056

[14] Weller, R.O. and Shulman, K. (1972) Infantile Hydrocephalus: Clinical, Histological, and Ultrastructural Study of Brain Damage. Journal of Neurosurgery, 36, 255-265. https://doi.org/10.3171/jns.1972.36.3.0255

[15] Dominguez-Pinos, M.D., Páez, P., Jiménez, A.J., Weil, B., Arraez, M.A., Pérez-Figares, J.M. and Rodríguez, E.M. (2005) Ependymal Denudation and Alterations of the Subventricular Zone Occur in Human Fetuses with a Moderate Communicating Hydrocephalus. Journal of Neuropathology \& Experimental Neurology, 64, 595-604. https://doi.org/10.1097/01.jnen.0000171648.86718.bb

[16] McAllister, J.P., II (2012) Pathophysiology of Congenital and Neonatal Hydrocephalus. Seminars in Fetal \& Neonatal Medicine, 17, 285-294.

https://doi.org/10.1016/j.siny.2012.06.004

[17] Russell, D.S. (1949) Observations on the Pathology of Hydrocephalus. Medical Research Council Special Report Series, 265, 1-138.

[18] Sarnat, H.B. (1992) Cerebral Dysgenesis. Embryology and Clinical Expression. Oxford University Press, New York.

[19] Clark, R.G. and Milhorat, T.H. (1970) Experimental Hydrocephalus. 3. Light Microscopic Findings in Acute and Subacute Obstructive Hydrocephalus in the Monkey. Journal of Neurosurgery, 32, 400-413. https://doi.org/10.3171/jns.1970.32.4.0400

[20] Diggs, J., Price, A.C., Burt, A.M., Flor, W.J., McKanna, J.A., Novak, G.R. and James, A.E. (1986) Early Changes in Experimental Hydrocephalus. Investigative Radiology, 21, 118-121. https://doi.org/10.1097/00004424-198602000-00006

[21] Page, R.B. (1975) Scanning Electron Microscopy of the Ventricular System in Normal and Hydrocephalic Rabbits. Preliminary Report and Atlas. Journal of Neurosurgery, 42, 646-664. https://doi.org/10.3171/jns.1975.42.6.0646

[22] Del Bigio, M.R. and Bruni, J.E. (1988a) Periventricular Pathology in Hydrocephalic Rabbits before and after Shunting. Acta Neuropathologica (BerI), 77, 186-195. https://doi.org/10.1007/BF00687430

[23] Page, R.B., Rosenstein, J.M., Dovey, B.J. and Leure-duPree, A.E. (1979) Ependymal Changes in Experimental Hydrocephalus. The Anatomical Record, 194, 83-104. https://doi.org/10.1002/ar.1091940106 
[24] Collins, P. (1979) Experimental Obstructive Hydrocephalus in the Rat: A Scanning Electron Microscopic Study. Neuropathology and Applied Neurobiology, 5, 457-468. https://doi.org/10.1111/j.1365-2990.1979.tb00643.x

[25] Raimondi, A.J., Bailey, O.T., McLone, D.G., Lawson, R.F. and Echeverry, A. (1973) The Pathophysiology and Morphology of Murine Hydrocephalus in hy-3 and Ch Mutants. Surgical Neurology, 1, 50-55.

[26] Go, K.G., Stokroos, I., Blaauw, E.H., Zuiderveen, F. and Molenaar, I. (1976) Changes of Ventricular Ependyma and Choroid Plexus in Experimental Hydrocephalus, as Observed by Scanning Electron Microscopy. Acta Neuropathologica, 34, 55-64. https://doi.org/10.1007/BF00684944

[27] Page, R.B. and Leure-duPree, A.E. (1983) Ependymal Alterations in Hydrocephalus. In: Wood, J.H., Ed., Neurobiology of Cerebrospinal Fluid, Vol. 2, Plenum Press, New York, 789-820. https://doi.org/10.1007/978-1-4615-9269-3_51

[28] Weller, R.O., Mitchell, J., Griffin, R.L. and Gardner, M.J. (1978) The Effects of Hydrocephalus upon the Developing Brain. Histological and Quantitative Studies of the Ependyma and Subependyma in Hydrocephalic Rats.Journal of the Neurological Sciences, 36, 383-402. https://doi.org/10.1016/0022-510X(78)90046-1

[29] Fleischhauer, K. (1972) Ependyma and Subependymal Layer. In: Bourne, G.H., Ed., The Structure and Function of Nervous Tissue, Vol. 6, Academic Press, New York, 1-46. https://doi.org/10.1016/B978-0-12-119286-0.50007-7

[30] Kaplan, M.S. (1983) Proliferation of Subependymal Cells in the Adult Primate CNS: Differential Uptake of DNA Labeled Precursors. Journal Fur Hirnforschung, 24, 23-33.

[31] Kazanis, I. (2009) The Subependymal Zone Neurogenic Niche: A Beating Heart in the Centre of the Brain. Brain, 132, 2909-2921. https://doi.org/10.1093/brain/awp237

[32] Doetsch, F., Garcia-Verdugo, J.M. and Alvarez-Buylla, A. (1999) Regeneration of a Germinal Layer in the Adult Mammalian Brain. Proceedings of the National Academy of Sciences, 96, 11619-11624. https://doi.org/10.1073/pnas.96.20.11619

[33] Morshead, C.M., Reynolds, B.A., Craig, C.G., McBurney, M.W., Staines, W.A., Morassutti, D., Weiss, S. and van der Kooy, D. (1994) Neural Stem Cells in the Adult Mammalian Forebrain: A Relatively Quiescent Subpopulation of Subependymal Cells. Neuron, 13, 1071-1082. https://doi.org/10.1016/0896-6273(94)90046-9

[34] Del Bigio, M.R. and McAllister, J.P., II (1999) Hydrocephalus-Pathology. In: Choux, M., Di Rocco, C., Hockley, A.D. and Walker, M.L., Eds., Pediatric Neurosurgery, Churchill Livingstone, London, 217-236.

[35] Di Curzio, D.L., Buist, R.J. and Del Bigio, M.R. (2013) Reduced Subventricular Zone Proliferation and White Matter Damage in Juvenile Ferrets with Kaolin-Induced Hydrocephalus. Experimental Neurology, 248, 112-128. https://doi.org/10.1016/j.expneurol.2013.06.004

[36] Di Curzio, D.L., Turner-Brannen, E. and Del Bigio, M.R. (2014) Oral Antioxidant Therapy for Juvenile Rats with Kaolin-Induced Hydrocephalus. Fluids and Barriers of the CNS, 11, 23. https://doi.org/10.1186/2045-8118-11-23

[37] Jiménez, A.J., García-Verdugo, J.M., González, C.A., Bátiz, L.F., Rodríguez-Pérez, L.M., Páez, P., Soriano-Navarro, M., Roales-Buján, R., Rivera, P., Rodríguez, S., Rodríguez, E.M. and Pérez-Fígares, J.M. (2009) Disruption of the Neurogenic Niche in the Subventricular Zone of Postnatal Hydrocephalic Hyh Mice. Journal of Neuropathology \& Experimental Neurology, 68, 1006-1020.

https://doi.org/10.1097/NEN.0b013e3181b44a5a 
[38] Miller, J.M. and McAllister, J.P., II (2007) Reduction of Astrogliosis and Microgliosis by Cerebrospinal Fluid Shunting in Experimental Hydrocephalus. Cerebrospinal Fluid Research, 4, 5. https://doi.org/10.1186/1743-8454-4-5

[39] Rubin, R.C., Hochwald, G.M., Tiell, M. and Liwnicz, B.H. (1976a) Hydrocephalus: II. Cell Number and Size, and Myelin Content of the Pre-Shunted Cerebral Cortical Mantle. Surgical Neurology, 5, 115-118.

[40] Del Bigio, M.R. and Zhang, Y.W. (1998) Cell Death, Axonal Damage, and Cell Birth in the Immature Rat Brain Following Induction of Hydrocephalus. Experimental Neurology, 154, 157-169. https://doi.org/10.1006/exnr.1998.6922

[41] Da Silva Lopes, L., Slobodian, I. and Del Bigio, M.R. (2009) Characterization of Juvenile and Young Adult Mice Following Induction of Hydrocephalus with Kaolin. Experimental Neurology, 219, 187-196. https://doi.org/10.1016/j.expneurol.2009.05.015

[42] Khan, O.H., Enno, T. and Del Bigio, M.R. (2006) Brain Damage in Neonatal Rats Following Kaolin Induction of Hydrocephalus. Experimental Neurology, 200, 311-320. https://doi.org/10.1016/j.expneurol.2006.02.113

[43] Mashayekhi, F., Draper, C.E., Bannister, C.M., Pourghasem, M., Owen-Lynch, P.J. and Miyan, J.A. (2002) Deficient Cortical Development in the Hydrocephalic Texas (H-Tx) Rat: A Role for CSF. Brain, 125, 1859-1874. https://doi.org/10.1093/brain/awf182

[44] Miyan, J.A., Khan, M.I., Kawarada, Y., Sugiyama, T. and Bannister, C.M. (1998) Cell Death in the Brain of the HTx Rat. European Journal of Pediatric Surgery, 8 , 43-48. https://doi.org/10.1055/s-2008-1071253

[45] Nojima, Y., Enzan, H., Hayashi, Y., Nakayama, H., Kiyoku, H., Hiroi, M. and Mori, K. (1998) Neuroepithelial and Ependymal Changes in HTX Rats with Congenital Hydrocephalus: An Ultrastructural and Immunohistochemical Study. Pathology International, 48, 115-125. https://doi.org/10.1111/j.1440-1827.1998.tb03880.x

[46] Owen-Lynch, P.J., Draper, C.E., Mashayekhi, F., Bannister, C.M. and Miyan, J.A. (2003) Defective Cell Cycle Control Underlies Abnormal Cortical Development in the Hydrocephalic Texas Rat. Brain, 126, 623-631.

https://doi.org/10.1093/brain/awg058

[47] Fukumitsu, H., Ohmiya, M., Nitta, A., Furukawa, S., Mima, T. and Mori, K. (2000) Aberrant Expression of Neurotrophic Factors in the Ventricular Progenitor Cells of Infant Congenitally Hydrocephalic Rats. Child s Nervous System, 16, 516-521. https://doi.org/10.1007/s003810000305

[48] Miyan, J.A., Mashayekhi, F. and Bannister, C.M. (2001) Developmental Abnormalities in Early-Onset Hydrocephalus: Clues to Signalling. Symposia of the Society for Experimental Biology, 53, 91-106.

[49] Oi, S., Ijichi, A. and Matsumoto, S. (1989) Immunohistochemical Evaluation of Neuronal Maturation in Untreated Fetal Hydrocephalus. Neurologia Medico-Chirurgica (Tokyo), 29, 989-994. https://doi.org/10.2176/nmc.29.989

[50] McAllister, J.P. II and Chovan, P. (1998) Neonatal Hydrocephalus. Mechanisms and Consequences. Neurosurgery Clinics of North America, 9, 73-93.

[51] Del Bigio, M.R., da Silva, M.C., Drake, J.M. and Tuor, U.I. (1994) Acute and Chronic Cerebral White Matter Damage in Neonatal Hydrocephalus. Canadian Journal of Neurological Sciences, 21, 299-305. https://doi.org/10.1017/S0317167100040865

[52] Gadsdon, D.R., Variend, S. and Emery, J.L. (1978) The Effect of Hydrocephalus 
upon the Myelination of the Corpus Callosum. Zeitschrift Fur Kinderchirurgie, 25, 311-319.

[53] Khan, O.H., McPhee, L.C., Moddemann, L.N. and Del Bigio, M.R. (2007) Calcium Antagonism in Neonatal Rats with Kaolin-Induced Hydrocephalus. Journal of Child Neurology, 22, 1161-1166. https://doi.org/10.1177/0883073807306259

[54] Mataro, M., Poca, M.A., Matarin, M., Sahuquillo, J., Sebastian, N. and Junque, C. (2006) Corpus Callosum Functioning in Patients with Normal Pressure Hydrocephalus before and after Surgery. Journal of Neurology, 253, 625-630. https://doi.org/10.1007/s00415-005-0073-Z

[55] Weller, R.O., Wisniewski, H., Shulman, K. and Terry, R.D. (1971) Experimental Hydrocephalus in Young Dogs: Histological and Ultrastructural Study of the Brain Tissue Damage. Journal of Neuropathology \& Experimental Neurology, 30, 613-627. https://doi.org/10.1097/00005072-197110000-00006

[56] Weller, R.O. and Wisniewski, H. (1969) Histological and Ultrastructural Changes with Experimental Hydrocephalus in Adult Rabbits. Brain Pathology, 92, 819-828. https://doi.org/10.1093/brain/92.4.819

[57] Hofmann, E., Becker, E., Jackel, M., Metzner, D., Schneider, M., Meixensberger, J. and Reichmann, H. (1995) The Corpus Callosum in Communicating and Noncommunicating Hydrocephalus. Neuroradiology, 37, 212-218.

https://doi.org/10.1007/BF01578260

[58] Jinkens, J.R. (1991) Clinical Manifestations of Hydrocephalus Caused by Impingemant of the Corpus Callosum on the Falx: An MR Study in 40 Patients. American Journal of Neuroradiology, 12, 331-340.

[59] Spreer, J., Ernestus, R.-I., Lanfermann, H. and Lackner, K. (1996) Lesions of the Corpus Callosum in Hydrocephalic Patients with Ventricular Drainage-A CT Study. Acta Neurochirurgica, 138, 174-178. https://doi.org/10.1007/BF01411357

[60] Del Bigio, M.R., Wilson, M.J. and Enno, T. (2003) Chronic Hydrocephalus in Rats and Humans: White Matter Loss and Behavior Changes. Annals of Neurology, 53, 337-346. https://doi.org/10.1002/ana.10453

[61] Hommet, C., Cottier, J.P., Billard, C., Perrier, D., Gillet, P., De Toffol, B., Sirinelli, D., Bertrand, P. and Autret, A. (2002) MRI Morphometric Study and Correlation with Cognitive Functions in Young Adults Shunted for Congenital Hydrocephalus Related to Spina Bifida. European Neurology, 47, 169-174. https://doi.org/10.1159/000047977

[62] D’Addario, V. and Kurjak, A. (1985) Ultrasound Investigation of the Fetal Cerebral Ventricles. Journal of Perinatal Medicine, 13, 67-77.

https://doi.org/10.1515/jpme.1985.13.2.67

[63] Oberbauer, R.W. (1985) The Significance of Morphological Details for Developmental Outcome in Infantile Hydrocephalus. Child's Nervous System, 1, 329-336. https://doi.org/10.1007/BF00270818

[64] De, S.N. (1950) A Study of the Changes in the Brain in Experimental Internal Hydrocephalus. The Journal of Pathology and Bacteriology, 62, 197-207. https://doi.org/10.1002/path.1700620207

[65] James, A.E., Jr., Flor, W.J., Novak, G.R., Strecker, E.P., Burns, B. and Epstein, M. (1977) Experimental Hydrocephalus. Experimental Eye Research, 25, 435-459. https://doi.org/10.1016/S0014-4835(77)80040-7

[66] Milhorat, T.H., Clark, R.G., Hammock, M.K. and McGrath, P.P. (1970) Structural, Ultrastructural, and Permeability Changes in the Ependyma and Surrounding Brain 
Favoring Equilibration in Progressive Hydrocephalus. Archives of Neurology, 22, 397-407. https://doi.org/10.1001/archneur.1970.00480230015002

[67] Del Bigio, M.R. (2000) Calcium-Mediated Proteolytic Damage in White Matter of Hydrocephalic Rats? Journal of Neuropathology \& Experimental Neurology, 59 946-954. https://doi.org/10.1093/jnen/59.11.946

[68] Del Bigio, M.R. (2001b) Future Directions for Therapy of Childhood Hydrocephalus: A View from the Laboratory. Pediatric Neurosurgery, 34, 172-181. https://doi.org/10.1159/000056016

[69] Di Rocco, C., di Tripani, G., Pettorossi, V.E. and Caldarelli, M. (1979) On the Pathology of Experimental Hydrocephalus Induced by Artificial Increase in Endoventricular CSF Pulse Pressure. Childs Brain, 5, 81-95.

[70] Miyagami, M., Nakamura, S., Murakami, T., Koga, N. and Moriyasu, M. (1976) Electron Microscopic Study of Ventricular Wall and Choroid Plexus in Experimentally-Induced Hydrocephalic Dogs. Neurologia Medico-Chirurgica (Tokyo), 16, 15-21. https://doi.org/10.2176/nmc.16pt1.15

[71] Shirai, T. and Ishii, K. (1991) Postnatal Changes of HRP-Labeled Corticospinal Neurons in Congenital Hydrocephalic Rats (HTX). In: Matsumoto, S. and Tamaki, N., Eds., Hydrocephalus Pathogenesis and Treatment, Springer-Verlag, Tokyo, 36-45. https://doi.org/10.1007/978-4-431-68156-4_4

[72] Yakovlev, P.I. (1947) Paraplegias of Hydrocephalus. A Clinical Note and Interpretation. American Journal of Mental Deficiency, 51, 561-576.

[73] Rubin, R.C., Hochwald, G.M., Tiell, M., Mizutani, H. and Ghatak, N. (1976b) Hydrocephalus: I. Histological and Ultrastructural Changes in the Pre-Shunted Cortical Mantle. Surgical Neurology, 5, 109-114.

[74] Sutton, L.N., Wood, H., Brooks, B.R., Barrer, S.J., Kline, M. and Cohen, S.R. (1983) Cerebrospinal Fluid Myelin Basic Protein in Hydrocephalus. Journal of Neurosurgery, 59, 467-470. https://doi.org/10.3171/jns.1983.59.3.0467

[75] Yamada, H., Yokota, A., Furuta, A. and Horie, A. (1992) Reconstitution of Shunted Mantle in Experimental Hydrocephalus. Journal of Neurosurgery, 76, 856-862. https://doi.org/10.3171/jns.1992.76.5.0856

[76] Feigin, I.H. (1983) White Matter Myelinolysis after Brain Edema. Bulletin De La Societe Belge D'Ophtalmologie, 208, 481-482.

[77] Leech, R.W. (1991) Pathologic Considerations. In: Leech, R.W. and Brumback, R.A., Eds., Hydrocephalus. Current Clinical Concepts, Mosby Year Book, St. Louis, 39-44.

[78] Felderhoff-Mueser, U., Buhrer, C., Groneck, P., Obladen, M., Bartmann, P. and Heep, A. (2003) Soluble Fas (CD95/Apo-1), Soluble Fas ligand, and Activated Caspase 3 in the Cerebrospinal Fluid of Infants with Posthemorrhagic and Nonhemorrhagic Hydrocephalus. Pediatric Research, 54, 659-664.

https://doi.org/10.1203/01.PDR.0000084114.83724.65

[79] Chumas, P.D., Drake, J.M., Del Bigio, M.R., Da Silva, M. and Tuor, U.I. (1994) Anaerobic Glycolysis Preceding White-Matter Destruction in Experimental Neonatal Hydrocephalus. Journal of Neurosurgery, 80, 491-501.

https://doi.org/10.3171/jns.1994.80.3.0491

[80] Del Bigio, M.R., Kanfer, J.N. and Zhang, Y.W. (1997a) Myelination Delay in the Cerebral White Matter of Immature Rats with Kaolin-Induced Hydrocephalus Is Reversible. Journal of Neuropathology \& Experimental Neurology, 56, 1053-1066. https://doi.org/10.1097/00005072-199709000-00010 
[81] Hanlo, P.W., Gooskens, R.J.H.M., Vanschooneveld, M., Tulleken, C.A.F., Vanderknaap, M.S., Faber, J.A.J. and Willemse, J. (1997) The Effect of Intracranial Pressure on Myelination and the Relationship with Neurodevelopment in Infantile Hydrocephalus. Developmental Medicine \& Child Neurology, 39, 286-291. https://doi.org/10.1111/j.1469-8749.1997.tb07433.x

[82] Mangano, F.T., McAllister, J.P., II, Jones, H.C., Johnson, M.J. and Kriebel, R.M. (1998) The Microglial Response to Progressive Hydrocephalus in a Model of Inherited Aqueductal Stenosis. Neurological Research, 20, 697-704. https://doi.org/10.1080/01616412.1998.11740586

[83] Asada, M., Tamaki, N., Kanazawa, Y., Matsumoto, S., Matsuo, M., Kimura, S., Fujii, S. and Kaneda, Y. (1978) Computer Analysis of Periventricular Lucency on the CT Scan. Neuroradiology, 16, 207-211. https://doi.org/10.1007/BF00395251

[84] Drake, J.M., Potts, D.G. and Lemaire, C (1989) Magnetic Resonance Imaging of Silastic-Induced Canine Hydrocephalus. Surgical Neurology, 31, 28-40. https://doi.org/10.1016/0090-3019(89)90215-2

[85] Hiratsuka, H., Tabata, H., Tsuruoka, S., Aoyagi, M., Okada, K. and Inaba, Y (1982) Evaluation of Periventricular Hypodensity in Experimental Hydrocephalus by $\mathrm{Me}$ trizamide CT Ventriculography. Journal of Neurosurgery, 56, 235-240. https://doi.org/10.3171/jns.1982.56.2.0235

[86] Fishman, R.A. and Greer, M. (1963) Experimental Obstructive Hydrocephalus. Changes in the Cerebrum. Archives of Neurology, 8, 156-161. https://doi.org/10.1001/archneur.1963.00460020056004

[87] Higashi, K., Asahisa, H., Ueda, N., Kobayashi, K., Hara, K. and Noda, Y. (1986) Cerebral Blood Flow and Metabolism in Experimental Hydrocephalus. Neurological Research, 8, 169-176. https://doi.org/10.1080/01616412.1986.11739750

[88] Hochwald, G.M., Boal, R.D., Marlin, A.E. and Kumar, A.J. (1975) Changes in Regional Blood-Flow and Water Content of Brain and Spinal Cord in Acute and Chronic Experimental Hydrocephalus. Developmental Medicine \& Child Neurology, 35, 42-50.

[89] Inaba, Y., Hirasuka, H., Tsuyuma, M., Tabata, H. and Tsuruoka, S (1984) Evaluation of Periventricular Hypodensity in Clinical and Experimental Hydrocephalus by Metrizamide Computed Tomography. In: Go, K.G. and Baethmann, A., Eds., Brain Edema, Plenum Press, New York, 299-310. https://doi.org/10.1007/978-1-4684-4616-6_29

[90] Takei, F., Shapiro, K., Hirano, A. and Kohn, I. (1987) Influence of the Rate of Ventricular Enlargement on the Ultrastructural Morphology of the White Matter in Experimental Hydrocephalus. Neurosurgery, 21, 645-650. https://doi.org/10.1227/00006123-198711000-00007

[91] Castejon, O.J. (2009) The Extracellular Space in the Edematous Human Cerebral Cortex: An Electron Microscopic Study using Cortical Biopsies. Ultrastructural Pathology, 33, 102-111. https://doi.org/10.1080/01913120902787076

[92] Di Rocco, C., Di Trapani, G., Maira, G., Bentivoglio, M., Macchi, G. and Rossi, G.F. (1977) Anatomo-Clinical Correlations in Normotensive Hydrocephalus. Reports on Three Cases. Journal of the Neurological Sciences, 33, 437-452. https://doi.org/10.1016/0022-510X(77)90139-3

[93] James, A.E., Jr., Flor, W.J., Novak, G.R., Ribas, J.L., Parker, J.L. and Sickel, W.L. (1980) The Ultrastructural Basis of Periventricular Edema: Preliminary Studies. Radiology, 135, 747-750. https://doi.org/10.1148/radiology.135.3.6770414

[94] Ogata, J., Hochwald, G.M., Cravioto, H. and Ransohoff, J. (1972) Light and Electron 
Microscopic Studies of Experimental Hydrocephalus. Ependymal and Subependymal Areas. Acta Neuropathologica (Berl), 21, 213-223. https://doi.org/10.1007/BF00688500

[95] Levin, V.A., Milhorat, T.H., Fenstermacher, J.D., Hammock, M.K. and Rall, D.P. (1971) Physiological Studies on the Development of Obstructive Hydrocephalus in the Monkey. Neurology, 21, 238-246. https://doi.org/10.1212/WNL.21.3.238

[96] Lux, W.E., Jr., Hochwald, G.M., Sahar, A. and Ransohoff, J. (1970) Periventricular Water Content. Effect of Pressure in Experimental Chronic Hydrocephalus. Archives of Neurology, 23, 475-479. https://doi.org/10.1001/archneur.1970.00480290095010

[97] Page, L.K. (1985) Cerebrospinal Fluid and Extracellular Fluid: Their Relationship to Pressure and Duration of Canine Hydrocephalus. Child s Nervous System, 1, 12-17. https://doi.org/10.1007/BF00706724

[98] Tamaki, N., Yamashita, H., Kimura, M., Ehara, K., Asada, M., Nagashima, T., Matsumoto, S. and Hashimoto, M. (1990) Changes in the Components and Content of Biological Water in the Brain of Experimental Hydrocephalic Rabbits. Journal of Neurosurgery, 73, 274-278. https://doi.org/10.3171/jns.1990.73.2.0274

[99] Pollay, M. and Curl, F. (1967) Secretion of Cerebrospinal Fluid by the Ventricular Ependyma of the Rabbit. American Journal of Physiology, 213, 1031-1038.

[100] McLone, D.G., Bondareff, W. and Raimondi, A.J. (1971) Brain Edema in the Hydrocephalic hy-3 Mouse: Submicroscopic Morphology. Journal of Neuropathology \& Experimental Neurology, 30, 627-637. https://doi.org/10.1097/00005072-197110000-00007

[101] McLone, D.G., Bondareff, W. and Raimondi, A.J. (1973) Hydrocephalus-3, a Murine Mutant: II. Changes in the Brain Extracellular Space. Surgical Neurology, 1, 233-242.

[102] Del Bigio, M.R. and Enno, T.L. (2008) Effect of Hydrocephalus on Rat Brain Extracellular Compartment. Cerebrospinal Fluid Research, 5, 12. https://doi.org/10.1186/1743-8454-5-12

[103] Foncin, J.F., Redondo, A. and LeBeau, J. (1976) Le Cortex Cerebral des malades attients d'hydrocephalie a pression normale: Etude ultrastructurale. Acta Neuropathologica, 34, 353-357. https://doi.org/10.1007/BF00696564

[104] Penn, R.D. and Bacus, J.W. (1984) The Brain as a Sponge: A Computed Tomographic Look at Hakim's Hypothesis. Neurosurgery, 14, 670-675. https://doi.org/10.1227/00006123-198406000-00004

[105] Azzi, G.M., Canady, A.I., Ham, S. and Mitchell, J.A. (1999) Kaolin-Induced Hydrocephalus in the Hamster: Temporal Sequence of Changes in Intracranial Pressure, Ventriculomegaly and Whole-Brain Specific Gravity. Acta Neuropathologica, 98, 245-250. https://doi.org/10.1007/s004010051076

[106] Del Bigio, M.R. and Bruni, J.E. (1987) Cerebral Water Content in Silicone Oil-Induced Hydrocephalic Rabbits. Pediatric Neuroscience, 13, 72-77. https://doi.org/10.1159/000120304

[107] Higashi, K., Noda, Y. and Tachibana, S. (1989) Study of Brain Tissue Impedance in the Hydrocephalic Cat. Journal of Neurology, Neurosurgery, and Psychiatry, 52, 636-642. https://doi.org/10.1136/jnnp.52.5.636

[108] Del Bigio, M.R. (1989) Hydrocephalus-Induced Changes in the Composition of Cerebrospinal Fluid. Neurosurgery, 25, 416-423. https://doi.org/10.1227/00006123-198909000-00016 
[109] Tarnaris, A., Watkins, L.D. and Kitchen, N.D. (2006) Biomarkers in Chronic Adult Hydrocephalus. Cerebrospinal Fluid Research, 3, 11. https://doi.org/10.1186/1743-8454-3-11

[110] Cohen, H.L., Haller, J.O. and Pollack, A. (1990) Ultrasound of the Septum Pellucidum. Recognition of Evolving Fenestrations in the Hydrocephalic Infant. Journal of Ultrasound in Medicine, 9, 377-383. https://doi.org/10.7863/jum.1990.9.7.377

[111] Friede, R.L. (1989) Developmental Neuropathology. 2nd Edition, Springer-Verlag, Berlin. https://doi.org/10.1007/978-3-642-73697-1

[112] Ulfig, N., Szabo, A. and Bohl, J. (2001) Effect of Fetal Hydrocephalus on the Distribution Patterns of Calcium-Binding Proteins in the Human Occipital Cortex. Pediatric Neurosurgery, 34, 20-32. https://doi.org/10.1159/000055988

[113] De Rosa, M.J., Olmstead, C.F., Peacock, W.J., Gayek, R.J., Vinters, H.V. and Fisher, R.S. (1992) Cortical Dysplasia in an Experimental Model of Hydrocephalus in the Rabbit. Journal of Neuropathology \& Experimental Neurology, 51, 339.

[114] Del Bigio, M.R., Cardoso, E.R. and Halliday, W.C. (1997b) Neuropathological Changes in Chronic Adult Hydrocephalus: Cortical Biopsies and Autopsy Findings. Canadian Journal of Neurological Sciences, 24, 121-126. https://doi.org/10.1017/S0317167100021442

[115] Ding, Y., McAllister, J.P., II, Yao, B., Yan, N. and Canady, A.I. (2001) Neuron Tolerance during Hydrocephalus. Neuroscience, 106, 659-667. https://doi.org/10.1016/S0306-4522(01)00166-X

[116] Ding, Y., McAllister, J.P., II, Yao, B., Yan, N. and Canady, A.I. (2001b) Axonal Damage Associated with Enlargement of Ventricles during Hydrocephalus: A Silver Impregnation Study. Neurological Research, 23, 581-587. https://doi.org/10.1179/016164101101199045

[117] Jones, H.C., Bucknall, R.M. and Harris, N.G. (1991) The Cerebral Cortex in Congenital Hydrocephalus in the H-Tx Rat: A Quantitative Light Microscopy Study. Acta Neuropathologica (BerI), 82, 217-224. https://doi.org/10.1007/BF00294448

[118] Jones, H.C., Harris, N.G., Rocca, J.R. and Andersohn, R.W. (1997) Progressive Changes in Cortical Metabolites at Three Stages of Infantile Hydrocephalus Studied by in Vitro NMR Spectroscopy. Journal of Neurotrauma, 14, 587-602. https://doi.org/10.1089/neu.1997.14.587

[119] Antoniou, A.G. and Emery, J.L. (1979) The Infundibulum of the Hypophysis in Hydrocephalus. Zeitschrift Fur Kinderchirurgie Grenzgeb, 28, 321-328.

[120] Auersperg, A. (1927) Das Verhalten der Kerne am Boden des III. Ventrikels bei Hydrozephalus. Arb Neurologisch Inst Wein Univ, 29, 163-169.

[121] Marburg, O. (1940) Hydrocephalus. Its Symptomology, Pathology, Pathogenesis and Treatment. Oskar Piest, New York.

[122] Berker, E., Goldstein, G., Lorder, J., Priestley, B. and Smith, A. (1992) Reciprocal Neurological Development of Twins Discordant for Hydrocephalus. Developmental Medicine \& Child Neurology, 34, 623-632. https://doi.org/10.1111/j.1469-8749.1992.tb11493.x

[123] Borit, A. and Sidman, R.L. (1972) New Mutant Mouse with Communicating Hydrocephalus and Secondary Aqueductal Stenosis. Acta Neuropathologica, 21, 316-331. https://doi.org/10.1007/BF00685139

[124] Castejon, O.J. (1994) Transmission Electron Microscopic Study of Human Hydrocephalic Cerebral Cortex. Journal of Submicroscopic Cytology and Pathology, 26, 29-39. 
[125] Castejon, O.J. (2004) Ultrastructural Pathology of Neuronal Membranes in the Oedematous Human Cerebral Cortex. Journal of Submicroscopic Cytology and Pathology, 36, 167-179.

[126] Harris, N.G., McAllister, J.P., II, Conaughty, J.M. and Jones, H.C. (1996) The Effect of Inherited Hydrocephalus and Shunt Treatment on Cortical Pyramidal Cell Dendrites in the Infant H-Tx Rat. Experimental Neurology, 141, 269-279. https://doi.org/10.1006/exnr.1996.0161

[127] Katayama, Y., Tsubokawa, T., Kinoshita, K., Koshinaga, M., Kawamata, T. and Miyazaki, S. (1991) Impaired Synaptic Plasticity and Dendritic Damage of Hippocampal CA1 Pyramidal Cells in Chronic Hydrocephalus. In: Matsumoto, S. and Tamaki, N., Eds., Hydrocephalus Pathogenesis and Treatment, Springer-Verlag, Tokyo, 58-67.

[128] McAllister, J.P., II, Maugans, T.A., Shah, M.V. and Truex, R.C., Jr. (1985) Neuronal Effects of Experimentally Induced Hydrocephalus in Newborn Rats. Journal of Neurosurgery, 63, 776-783. https://doi.org/10.3171/jns.1985.63.5.0776

[129] Klinge, P., Mühlendyck, A., Lee, S., Ludemann,W., Groos, S., Samii, M. and Brinker, T. (2002) Temporal and Regional Profile of Neuronal and Glial Cellular Injury after Induction of Kaolin Hydrocephalus. Acta Neurochirurgica, 81, 275-277. https://doi.org/10.1007/978-3-7091-6738-0_71

[130] Kriebel, R.M. and McAllister, J.P., II (2000) Pathology of the Hippocampus in Experimental Feline Infantile Hydrocephalus. Neurological Research, 22, 29-36. https://doi.org/10.1080/01616412.2000.11741035

[131] Miyazawa, T., Nishiye, H., Sato, K., Kobayashi, R., Hattori, S., Shirai, T. and Obata, K. (1992) Cortical Synaptogenesis in Congenitally Hydrocephalic HTX-Rats using Monoclonal Anti-Synaptic Vesicle Protein Antibody. Brain \& Development, 14 75-79. https://doi.org/10.1016/S0387-7604(12)80089-1

[132] Suda, K., Sato, K., Miyazawa, T. and Arai, H. (1994) Changes of Synapse-Related Proteins (SVP-38 and Drebrins) during Development of Brain in Congenitally Hydrocephalic HTX Rats with and without Early Placement of Ventriculoperitoneal Shunt. Pediatric Neurosurgery, 20, 50-56. https://doi.org/10.1159/000120764

[133] Glees, P. and Voth, D. (1988) Clinical and Ultrastructural Observations of Maturing Human Frontal Cortex. Part I (Biopsy Material of Hydrocephalic Infants). Neurosurgical Review, 11, 273-278. https://doi.org/10.1007/BF01741422

[134] Penfield, W. (1929) Notes on Cerebral Pressure Atrophy. Association for Research in Nervous and Mental Disease, 8, 246-362.

[135] Hassin, G.B. (1932) Hydrocephalus: Studies of the Pathology and Pathogenesis with Remarks on the Cerebrospinal Fluid. Archives of Neurology and Psychiatry, 24, 1164-1186. https://doi.org/10.1001/archneurpsyc.1930.02220180061005

[136] Del Bigio, M.R. and Bruni, J.E. (1991) Silicone Oil-Induced Hydrocephalus in the Rabbit. Child s Nervous System, 7, 79-84. https://doi.org/10.1007/BF00247861

[137] Gopinath, G., Bhatia, R. and Gopinath, P.G. (1979) Ultrastructural Observations in Experimental Hydrocephalus in the Rabbit. Journal of the Neurological Sciences, 43, 333-344. https://doi.org/10.1016/0022-510X(79)90013-3

[138] Hale, P.M., McAllister, J.P., II, Katz, S.D., Wright, L.C., Lovely, T.J., Miller, D.W., Wolfson, B.J., Salotto, A.G. and Shroff, D.V. (1992) Improvement of Cortical Morphology in Infantile Hydrocephalic Animals after Ventriculoperitoneal Shunt Placement. Neurosurgery, 31, 1085-1096.

https://doi.org/10.1227/00006123-199212000-00015 
[139] Miyan, J.A., Khan, M.I., Bowers, T.M. and Bannister, C.M. (1997) Effects of Hydrocephalus on Nitric Oxide Neurones in the Brain of the HTx Rat. European Journal of Pediatric Surgery, 7, 23-27. https://doi.org/10.1055/s-2008-1071204

[140] Mori, F., Tanji, K., Yoshida, Y. and Wakabayashi, K. (2002) Thalamic Retrograde Degeneration in the Congenitally Hydrocephalic Rat Is Attributable to Apoptotic Cell Death. Neuropathology, 22, 186-193. https://doi.org/10.1046/j.1440-1789.2002.00445.x

[141] Tashiro, Y., Chakrabortty, S., Drake, J.M. and Hattori, T. (1997) Progressive Loss of Glutamic Acid Decarboxylase, Parvalbumin, and Calbindin D28K Immunoreactive Neurons in the Cerebral Cortex and Hippocampus of Adult Rat with Experimental Hydrocephalus. Journal of Neurosurgery, 86, 263-271. https://doi.org/10.3171/jns.1997.86.2.0263

[142] Ulfig, N. (2002) Neuronal Vacuolation in the Basal Nucleus of Meynert Caused by Fetal Hydrocephalus. Pediatric Neurosurgery, 36, 320-323. https://doi.org/10.1159/000063536

[143] Wright, L.C., McAllister, J.P., II, Katz, S.D., Miller, D.W., Lovely, T.J., Salotto, A.G. and Wolfson, B.J. (1990-91) Cytological and Cytoarchitectural Changes in the Feline Cerebral Cortex during Experimental Infantile Hydrocephalus. Pediatric Neurosurgery, 16, 139-155. https://doi.org/10.1159/000120516

[144] Ball, M.J. (1976) Neurofibrillary Tangles in the Dementia of "Normal Pressure" Hydrocephalus. Canadian Journal of Neurological Sciences, 3, 227-235. https://doi.org/10.1017/S0317167100025348

[145] Bech, R.A., Juhler, M., Waldemar, G., Klinken, L. and Gjerris, F. (1997) Frontal Brain and Leptomeningeal Biopsy Specimens Correlated with Cerebrospinal Fluid Outflow Resistance and B Wave Activity in Patients Suspected of Normal Pressure Hydrocephalus. Neurosurgery, 40, 497-502.

[146] Bech, R.A., Waldemar, G., Gjerris, F., Klinken, L. and Juhler, M. (1999) Shunting Effects in Patients with Idiopathic Normal Pressure Hydrocephalus; Correlation with Cerebral and Leptomeningeal Biopsy Findings. Acta Neurochirurgica, 141, 633-639. https://doi.org/10.1007/s007010050353

[147] Fan, K.J. and Pezeshkpour, G. (1987) Neurofibrillary Tangles in Association with Congenital Hydrocephalus. Journal of the National Medical Association, 79, 1001-1003.

[148] Golomb, J., Wisoff, J., Miller, D.C., Boksay, I., Kluger, A., Weiner, H., Salton, J. and Graves, W. (2000) Alzheimer's Disease Comorbidity in Normal Pressure Hydrocephalus: Prevalence and Shunt Response. Journal of Neurology, Neurosurgery, and Psychiatryy, 68, 778-781. https://doi.org/10.1136/jnnp.68.6.778

[149] Wisniewski, H.M., Popovitch, E.R., Kaufman, M.A. and Wisniewski, K.E. (1987) Neurofibrillary Changes in Advanced Hydrocephalus. A Clinicopathological Study. Journal of Neuropathology \& Experimental Neurology, 46, 340. https://doi.org/10.1097/00005072-198705000-00032

[150] Miyajima, M., Sato, K. and Arai, H. (1996) Choline Acetyltransferase, Nerve Growth Factor and Cytokine Levels Are Changed in Congenitally Hydrocephalic HTX Rats. Pediatric Neurosurgery, 24, 1-4. https://doi.org/10.1159/000121007

[151] Shinoda, M., Hidaka, M., Lindqvist, E., Soderstrom, S., Matsumae, M., Oi, S., Sato, O., Tsugane, R., Ebendal, T. and Olson, L. (2001) NGF, NT-3 and Trk C mRNAs, but not TrkA mRNA, Are Upregulated in the Paraventricular Structures in Experimental Hydrocephalus. Child's Nervous System, 17, 704-712. https://doi.org/10.1007/s00381-001-0515-6 
[152] Yamada, Y., Watanabe, Y., Zhang, J., Haraoka, J. and Ito, H. (2002) Changes in Cortical and Cerebellar bcl-2 mRNA Levels in the Developing Hydrocephalic Rat (LEW-HYR) as Measured by a Real Time Quantified RT-PCR. Neuroscience, 114, 165-171. https://doi.org/10.1016/S0306-4522(02)00210-5

[153] Zhang, Y.W. and Del Bigio, M.R. (1998) Growth-Associated Protein-43 Is Increased in Cerebrum of Immature Rats Following Induction of Hydrocephalus. Neuroscience, 86, 847-854. https://doi.org/10.1016/S0306-4522(98)00080-3

[154] Barf, H.A., Verhoef, M., Jennekens-Schinkel, A., Post, M.W., Gooskens, R.H. and Prevo, A.J. (2003) Cognitive Status of Young Adults with Spina Bifida. Developmental Medicine \& Child Neurology, 45, 813-820. https://doi.org/10.1111/j.1469-8749.2003.tb00896.x

[155] Chaudhry, P., Kharkar, S., Heidler-Gary, J., Hillis, A.E., Newhart, M., Kleinman, J.T., Davis, C., Rigamonti, D., Wang, P., Irani, D.N. and Williams, M.A. (2007) Characteristics and Reversibility of Dementia in Normal Pressure Hydrocephalus. Behavioural Neurology, 18, 149-158. https://doi.org/10.1155/2007/456281

[156] Dennis, M., Jewell, D., Drake, J., Misakyan, T., Spiegler, B., Hetherington, R., Gentili, F. and Barnes, M. (2007) Prospective, Declarative, and Nondeclarative Memory in Young Adults with Spina Bifida. Journal of the International Neuropsychological Society, 13, 312-323. https://doi.org/10.1017/S1355617707070336

[157] Egawa, T., Mishima, K., Egashira, N., Fukuzawa, M., Abe, K., Yae, T., Iwasaki, K. and Fujiwara, M. (2002) Impairment of Spatial Memory in Kaolin-Induced Hydrocephalic Rats Is Associated with Changes in the Hippocampal Cholinergic and Noradrenergic Contents. Behavioural Brain Research, 129, 31-39. https://doi.org/10.1016/S0166-4328(01)00333-3

[158] Lindquist, B., Persson, E.K., Uvebrant, P. and Carlsson, G. (2008) Learning, Memory and Executive Functions in Children with Hydrocephalus. Acta Paediatrica, 97, 596-601. https://doi.org/10.1111/j.1651-2227.2008.00747.x

[159] Vachha, B., Adams, R.C. and Rollins, N.K. (2006) Limbic Tract Anomalies in Pediatric Myelomeningocele and Chiari II Malformation: Anatomic Correlations with Memory and Learning-Initial Investigation. Radiology, 240, 194-202. https://doi.org/10.1148/radiol.2401050674

[160] Hawkins, D., Bowers, T.M., Bannister, C.M. and Miyan, J.A. (1997) The Functional Outcome of Shunting H-Tx Rat Pups at Different Ages. European Journal of Pediatric Surgery, 7, 31-34. https://doi.org/10.1055/s-2008-1071206

[161] Jones, H.C., Rivera, K.M. and Harris, N.G. (1995) Learning Deficits in Congenitally Hydrocephalic Rats and Prevention by Early Shunt Treatment. Child s Nervous System, 11, 655-660. https://doi.org/10.1007/BF00300725

[162] Miyazawa, T. and Sato, K. (1991) Learning Disability and Impairment of Synaptogenesis in HTX-Rats with Arrested Shunt-Dependent Hydrocephalus. Childs Nervous System, 7, 121-128. https://doi.org/10.1007/BF00776706

[163] Shim, I., Ha, Y., Chung, J.Y., Lee, H.J., Yang, K.H. and Chang, J.W. (2003) Association of Learning and Memory Impairments with Changes in the Septohippocampal Cholinergic System in Rats with Kaolin-Induced Hydrocephalus. Neurosurgery, 53, 416-425. https://doi.org/10.1227/01.NEU.0000073989.07810.D8

[164] Donnet, A., Schmitt, A., Dufour, H., Giorgi, R. and Grisoli, F. (2004) Differential Patterns of Cognitive Impairment in Patients with Aqueductal Stenosis and Normal Pressure Hydrocephalus. Acta Neurochirurgica (Wien), 146, 1301-1308. https://doi.org/10.1007/s00701-004-0384-3

[165] Bucknall, R.M. and Jones, H.C. (1990) Electrocorticogram and Sensory Evoked Po- 
tentials in the Young Hydrocephalic H-Tx Rat. Zeitschrift Fur Kinderchirurgie, 45, 8-10.

[166] Chiba, A., Ohta, Y., Oshio, K. and Inase, M. (2003) Motor Evoked Potentials in Rats with Congenital Hydrocephalus. Neurological Research, 25, 305-308. https://doi.org/10.1179/016164103101201391

[167] Imamura, K., Tanaka, S., Ribot, J., Kobayashi, M., Yamamoto, M., Nakadate, K. and Watanabe, Y. (2006) Preservation of Functional Architecture in Visual Cortex of Cats with Experimentally Induced Hydrocephalus. European Journal of Neuroscience, 23, 2087-2098. https://doi.org/10.1111/j.1460-9568.2006.04729.x

[168] Röricht, S., Meyer, B.U., Woiciechowsky, C. and Lehmann, R. (1998) Callosal and Corticospinal Tract Function in Patients with Hydrocephalus: A Morphometric and Transcranial Magnetic Stimulation Study. Journal of Neurology, 245, 280-288. https://doi.org/10.1007/s004150050219

[169] Van Eijsden, P., Braun, K.P.J., Vandertop, W.P., Gooskens, R., Gispen, W.H. and Biessels, G. (2000) Visual Evoked Potentials and Brainstem Auditory Evoked Potentials in Experimental Hydrocephalus. European Journal of Pediatric Surgery, 1, 47-48.

[170] Zaaroor, M., Bleich, N., Chistyakov, A., Pratt, H. and Feinsod, M (1997) Motor Evoked Potentials in the Preoperative and Postoperative Assessment of Normal Pressure Hydrocephalus. Journal of Neurology, Neurosurgery, and Psychiatry, 62, 517-521. https://doi.org/10.1136/jnnp.62.5.517

[171] Tsubokawa, T., Katayama, Y. and Kawamata, T. (1988) Impaired Hippocampal Plasticity in Experimental Chronic Hydrocephalus. Brain Injury, 2, 19-30. https://doi.org/10.3109/02699058809150929

[172] Yinon, U., Chen, M. and Milgram, A. (1990) Hydrocephalus in Developing Cats: Physiological Properties of Visual Cortex cells. Brain Research Bulletin, 25, 651-663. https://doi.org/10.1016/0361-9230(90)90039-3

[173] Barkovich, A.J. and Newton, T.H. (1989) MR of Aqueductal Stenosis: Evidence of a Broad Spectrum of Tectal Distortion. American Journal of Neuroradiology, 10, 471-476.

[174] Cinalli, G., Sainte-Rose, C., Simon, I., Lot, G. and Sgouros, S. (1999) Sylvian Aqueduct Syndrome and Global Rostral Midbrain Dysfunction Associated with Shunt Malfunction. Journal of Neurosurgery, 90, 227-236. https://doi.org/10.3171/jns.1999.90.2.0227

[175] Desch, L.W. (2001) Longitudinal Stability of Visual Evoked Potentials in Children and Adolescents with Hydrocephalus. Developmental Medicine \& Child Neurology, 43, 113-117. https://doi.org/10.1017/S0012162201000196

[176] Ito, J., Saijo, H., Araki, A., Tanaka, H., Tasaki, T., Cho, K. and Miyamoto A. (1997) Neuroradiological Assessment of Visuoperceptual Disturbance in Children with Spina Bifida and Hydrocephalus. Developmental Medicine \& Child Neurology, 39, 385-392. https://doi.org/10.1111/j.1469-8749.1997.tb07451.x

[177] Shallat, R.F., Pawl, R.P. and Jerva, M.J. (1973) Significance of Upward Gaze Palsy (Parinaud's Syndrome) in Hydrocephalus Due to Shunt Malfunction. Journal of Neurosurgery, 38, 717-721. https://doi.org/10.3171/jns.1973.38.6.0717

[178] Del Bigio, M.R., Bruni, J.E. and Vriend, J.P. (1998) Monoamine Neurotransmitters and Their Metabolites in the Mature Rabbit Brain Following Induction of Hydrocephalus. Neurochemical Research, 23, 1379-1386.

https://doi.org/10.1023/A:1020798622692 
[179] Del Bigio, M.R. and Vriend, J.P. (1998) Monoamine Neurotransmitters and Amino Acids in the Cerebrum and Striatum of Immature Rats with Kaolin-Induced Hydrocephalus. Brain Research, 798, 119-126. https://doi.org/10.1016/S0006-8993(98)00404-1

[180] Ehara, K., Tanaka, C., Tamaki, N. and Matsumoto, S. (1991) Changes in the Hypothalamic and Brain Stem Catecholaminergic Systems in Experimental Hydrocephalus: A Histochemical Observation. In: Matsumoto S, and Tamaki N., Eds., Hydrocephalus: Pathogenesis and Treatment, Springer-Verlag, Tokyo, 75-87.

[181] Harris, N.G., Plant, H.D., Inglis, B.A., Briggs, R.W. and Jones, H.C. (1997) Neurochemical Changes in the Cerebral Cortex of Treated and Untreated Hydrocephalic rat Pups Quantified with in Vitro 1H-NMR Spectroscopy. Journal of Neurochemistry, 68, 305-312. https://doi.org/10.1046/j.1471-4159.1997.68010305.x

[182] Hwang, Y.S., Shim, I. and Chang, J.W. (2009) The Behavioral Change of Locomotor Activity in a Kaolin-Induced Hydrocephalus Rat Model: Evaluation of the Effect on the Dopaminergic System with Progressive Ventricle Dilatation. Neuroscience Letters, 462, 198-202. https://doi.org/10.1016/j.neulet.2009.07.039

[183] Ishizaki, R., Tashiro, Y., Inomoto, T. and Hashimoto, N. (2000) Acute and Subacute Hydrocephalus in a Rat Neonatal Model: Correlation with Functional Injury of Neurotransmitter Systems. Pediatric Neurosurgery, 33, 298-305. https://doi.org/10.1159/000055975

[184] Nakayama, T., Ouchi, Y., Yoshikawa, E., Sugihara, G., Torizuka, T. and Tanaka, K. (2007) Striatal D2 Receptor Availability after Shunting in Idiopathic Normal Pressure Hydrocephalus. Journal of Nuclear Medicine, 48, 1981-1986. https://doi.org/10.2967/jnumed.107.045310

[185] Otsubo, Y., Ito, H. and Shibuya, T. (1997) Intracerebral Monoamine Concentration after Ventriculoperitoneal Shunting in the Congenital Hydrocephalus Rat. Neurologia Medico-Chirurgica (Tokyo), 37, 669-676. https://doi.org/10.2176/nmc.37.669

[186] Ouchi, Y., Nakayama, T., Kanno, T., Yoshikawa, E., Shinke, T. and Torizuka, T. (2007) In Vivo Presynaptic and Postsynaptic Striatal Dopamine Functions in Idiopathic Normal Pressure Hydrocephalus. Journal of Cerebral Blood Flow \& Metabolism, 27, 803-810. https://doi.org/10.1038/sj.jcbfm.9600389

[187] Tashiro, Y. and Drake, J.M. (1998) Reversibility of Functionally Injured Neurotransmitter Systems with Shunt Placement in Hydrocephalic Rats: Implications for Intellectual Impairment in Hydrocephalus. Journal of Neurosurgery, 88, 709-717. https://doi.org/10.3171/jns.1998.88.4.0709

[188] Tashiro, Y., Drake, J.M., Chakrabortty, S. and Hattori T. (1997b) Functional Injury of Cholinergic, GABAergic and Dopaminergic Systems in the Basal Ganglia of Adult Rat with Kaolin-Induced Hydrocephalus. Brain Research, 770, 45-52. https://doi.org/10.1016/S0006-8993(97)00742-7

[189] Harris, N.G., Plant, H.D., Briggs, R.W. and Jones, H.C. (1996b) Metabolite Changes in the Cerebral Cortex of Treated and Untreated Infant Hydrocephalic Rats Studied using in Vitro 31P-NMR Spectroscopy. Journal of Neurochemistry, 67, 2030-2038. https://doi.org/10.1046/j.1471-4159.1996.67052030.x

[190] Kondziella, D., Ludemann, W., Brinker, T., Sletvold, O. and Sonewald, U. (2002) Alterations in Brain Metabolism, CNS Morphology and CSF Dynamics in Adult Rats with Kaolin-Induced Hydrocephalus. Brain Research, 927, 35-41. https://doi.org/10.1016/S0006-8993(01)03320-0

[191] Abdolvahabi, R.M., Mitchell, J.A., Diaz, F.G. and McAllister, J.P., II (2000) A Brief Review of the Effects of Chronic Hydrocephalus on the Gonadotropin Releasing 
Hormone System: Implications for Amenorrhea and Precocious Puberty. Neurological Research, 22, 123-126. https://doi.org/10.1080/01616412.2000.11741047

[192] Lopponen, T., Saukkonen, A.L., Serlo, W., Tapanainen, P., Ruokonen, A. and Knip, M. (1996) Accelerated Pubertal Development in Patients with Shunted Hydrocephalus. Archives of Disease in Childhood, 74, 490-496. https://doi.org/10.1136/adc.74.6.490

[193] Lopponen, T., Paakko, E., Laitinen, J., Saukkonen, A.L., Serlo, W., Tapanainen, P., Ruokonen, A., Pirttiniemi, P., Poikela, A. and Knip, M. (1997) Pituitary Size and Function in Children and Adolescents with Shunted Hydrocephalus. Clinical Endocrinology, 46, 691-699. https://doi.org/10.1046/j.1365-2265.1997.1931004.x

[194] McAllister, J.P., II, Abdolvahabi, R.M., Walker, M.L., Mitchell, J.A. and Jones, H.C. (2007) Effects of Congenital Hydrocephalus on the Hypothalamic Gonadotrophin-Releasing Hormone System. Neurosurgical Focus, 22, E4. https://doi.org/10.3171/foc.2007.22.4.5

[195] Trollmann, R., Strehl, E., Wenzel, D. and Dorr, H.G. (2000) Does Growth Hormone (GH) Enhance Growth in GH-Deficient Children with Myelomeningocele? The Journal of Clinical Endocrinology \& Metabolism, 85, 2740-2743. https://doi.org/10.1210/jcem.85.8.6724

[196] Yoshino, M., Yoshimi, Y., Taniguchi, M., Nakamura, S. and Ikeda, T. (1999) Syndrome of Inappropriate Secretion of Antidiuretic Hormone Associated with Idiopathic Normal Pressure Hydrocephalus. Internal Medicine, 38, 290-292. https://doi.org/10.2169/internalmedicine.38.290

[197] Juranek, J., Dennis, M., Cirino, P.T., El-Messidi, L. and Fletcher, J.M. (2010) The Cerebellum in Children with Spina Bifida and Chiari II Malformation: Quantitative Volumetrics by Region. Cerebellum, 9, 240-248.

https://doi.org/10.1007/s12311-010-0157-x

[198] Emery, J.L. (1967) Kinking of the Medulla in Children with Acute Cerebral Oedema and Hydrocephalus and Its Relationship to the Dentate Ligaments. Journal of Neurology, Neurosurgery, and Psychiatry, 30, 267-275. https://doi.org/10.1136/jnnp.30.3.267

[199] Koehler, P.J. (1991) Chiari's Description of Cerebellar Ectopy (1891) with a Summary of Cleland's and Arnold's Contributions and Some Early Observations on Neural-Tube Defects. Journal of Neurosurgery, 75, 823-826. https://doi.org/10.3171/jns.1991.75.5.0823

[200] Variend, S. and Emery, J.L. (1974) The Pathology of the Central Lobes of the Cerebellum in Children with Myelomeningocele. Developmental Medicine \& Child Neurology, 16, 99-106. https://doi.org/10.1111/j.1469-8749.1974.tb03457.x

[201] Variend, S. and Emery, J.L. (1979) The Superior Surface Lesion of the Cerebellum in Children with Myelomeningocele. Zeitschrift Fur Kinderchirurgie Grenzgeb, 28, 328-335.

[202] Emery, J.L. and Gadsdon, D.R. (1975) A Quantitative Study of the Cell Population of the Cerebellum in Children with Myelomeningocele. Developmental Medicine \& Child Neurology, 35, 20-25. https://doi.org/10.1111/j.1469-8749.1975.tb03575.x

[203] Boltshauser, E. (2004) Cerebellum-Small Brain But Large Confusion: A Review of Selected Cerebellar Malformations and Disruptions. American Journal of Medical Genetics Part A, 126, 376-385. https://doi.org/10.1002/ajmg.a.20662

[204] Boltshauser, E., Schneider, J., Kollias, S., Waibel, P. and Weissert, M. (2002) Vanishing Cerebellum in Myelomeningocoele. European Journal of Paediatric Neurology, 6, 109-113. https://doi.org/10.1053/ejpn.2001.0556 
[205] Poretti, A., Prayer, D. and Boltshauser, E. (2009) Morphological Spectrum of Prenatal Cerebellar Disruptions. European Journal of Paediatric Neurology, 13, 397-407. https://doi.org/10.1016/j.ejpn.2008.09.001

[206] Chovanes, G.I., McAllister, J.P., II, Lamperti, A.A., Salotto, A.G. and Truex, R.C., Jr. (1988) Monoamine Alterations during Experimental Hydrocephalus in Neonatal Rats. Neurosurgery, 22, 86-91. https://doi.org/10.1227/00006123-198801000-00014

[207] Socci, D., Bjugstad, K.B., Jones, H.C., Pattisapu, J.V. and Arendash, G.W. (1999) Evidence that Oxidative Stress Is Associated with the Pathophysiology of Inherited Hydrocephalus in the H-Tx Rat Model. Experimental Neurology, 155, 109-117. https://doi.org/10.1006/exnr.1998.6969

[208] Dennis, M., Landry, S.H., Barnes, M. and Fletcher, J.M. (2006) A Model of Neurocognitive Function in Spina Bifida over the Life Span. Journal of the International Neuropsychological Society, 12, 285-296.

https://doi.org/10.1017/S1355617706060371

[209] Braun, K.P., Vandertop, W.P., Gooskens, R.H., Tulleken, K.A. and Nicolay, K. (2000) NMR Spectroscopic Evaluation of Cerebral Metabolism in Hydrocephalus: A Review. Neurological Research, 22, 51-64. https://doi.org/10.1080/01616412.2000.11741038

[210] Chang, C.C., Asada, H., Mimura, T. and Suzuki, S. (2009) A Prospective Study of Cerebral Blood Flow and Cerebrovascular Reactivity to Acetazolamide in $162 \mathrm{~Pa}$ tients with Idiopathic Normal-Pressure Hydrocephalus. Journal of Neurosurgery, 111, 610-617. https://doi.org/10.3171/2008.10.17676

[211] Del Bigio, M.R. and Bruni, J.E. (1988b) Changes in Periventricular Vasculature of Rabbit Brain Following Induction of Hydrocephalus and after Shunting. Journal of Neurosurgery, 69, 115-120. https://doi.org/10.3171/jns.1988.69.1.0115

[212] Owler, B.K. and Pickard, J.D. (2001) Normal Pressure Hydrocephalus and Cerebral Blood Flow: A Review. Acta Neurologica Scandinavica, 104, 325-342. https://doi.org/10.1034/j.1600-0404.2001.00092.x

[213] Richards, H.K., Bucknall, R.M., Jones, H.C. and Pickard, J.D. (1995) Uncoupling of LCBF and LCGU in Two Different Models of Hydrocephalus: A Review. Child $s$ Nervous System, 11, 288-292. https://doi.org/10.1007/BF00301762

[214] Massicotte, E.M., Buist, R. and Del Bigio, M.R. (2000) Altered Diffusion and Perfusion in Hydrocephalic Rat Brain: A Magnetic Resonance Imaging Analysis. Journal of Neurosurgery, 92, 442-447. https://doi.org/10.3171/jns.2000.92.3.0442

[215] Goh, D. and Minns, R.A. (1995) Intracranial Pressure and Cerebral Arterial Flow Velocity Indices in Childhood Hydrocephalus: Current Review. Childs Nervous System, 11, 392-396. https://doi.org/10.1007/BF00717403

[216] Hill, A. and Volpe, J.J. (1982) Decrease in Pulsatile Flow in the Anterior Cerebral Arteries in Infantile Hydrocephalus. Pediatrics, 69, 4-7.

[217] Lui, K., Hellmann, J., Sprigg, A. and Daneman, A (1990) Cerebral Blood Flow Velocity Patterns in Post-Hemorrhagic Ventricular Dilatation. Child s Nervous System, 6, 250-253. https://doi.org/10.1007/BF00307660

[218] Shirane, R., Sato, S., Sato, K., Kameyama, M., Ogawa, A., Yoshimoto, T., Hatazawa, J. and Ito, M. (1992) Cerebral Blood Flow and Oxygen Metabolism in Infants with Hydrocephalus. Child s Nervous System, 8, 118-123. https://doi.org/10.1007/BF00298263

[219] Shih, W.J. and Tasdemiroglu, E. (1995) Reversible Hypoperfusion of the Cerebral Cortex in Normal-Pressure Hydrocephalus on Technetium-99m-HMPAO Brain 
SPECT Images after Shunt Operation. Journal of Nuclear Medicine, 36, 470-473.

[220] Sato, H., Sato, N., Tamaki, N. and Matsumoto, S. (1988) Threshold of Cerebral Perfusion Pressure as a Prognostic Factor in Hydrocephalus during Infancy. Childs Nervous System, 4, 274-278.

[221] Hidaka, M., Matsumae, M., Yamamura, M., Tsugane, R. and Sato, O. (1997) Glucose Metabolism and Protective Biochemical Mechanisms in a Rat Brain Affected by Kaolin-Induced Hydrocephalus. Child s Nervous System, 13, 183-188. https://doi.org/10.1007/s003810050066

[222] Klinge, P.M., Samii, A., Mühlendyck, A., Visnyei, K., Meyer, G.J., Walter, G.F., Silverberg, G.D. and Brinker, T. (2003) Cerebral Hypoperfusion and Delayed Hippocampal Response after Induction of Adult Kaolin Hydrocephalus. Stroke, 34, 193-199. https://doi.org/10.1161/01.STR.0000048820.17198.15

[223] Matsumae, M., Sogabe, T., Miura, I. and Sato, O. (1990) Energy Metabolism in Kaolin-Induced Hydrocephalic Rat Brain Assessed by Phosphorus (P31) Magnetic Resonance Spectroscopy and the Diversity of Lactate Dehydrogenase and Its Isoenzyme Patterns. Child s Nervous System, 6, 392-396.

https://doi.org/10.1007/BF00302225

[224] Richards, H.K., Pickard, J.D. and Punt, J. (1985) Local Cerebral Glucose Utilization in Experimental Chronic Hydrocephalus in the Rat. Zeitschrift Fur Kinderchirurgie, 40,9 .

[225] Luciano, M.G., Skarupa, D.J., Booth, A.M., Wood, A.S., Brant, C.L. and Gdowski, M.J. (2001) Cerebrovascular Adaptation in Chronic Hydrocephalus. Journal of Cerebral Blood Flow \& Metabolism, 21, 285-294. https://doi.org/10.1097/00004647-200103000-00012

[226] Nakada, J., Oka, N., Nagahori, T., Endo, S. and Takaku, A. (1992) Changes in the Cerebrovascular Bed in Experimental Hydrocephalus: An Angio-Architectural and Histological Study. Acta Neurochirurgica, 114, 43-50. https://doi.org/10.1007/BF01401113

[227] Okuyama, T., Hashi, K., Sasaki, S., Sudo, K. and Kurokawa, Y. (1987) Changes in Cerebral Microvasculature in Congenital Hydrocephalus of the Inbred Rat LEW/Jms: Light and Electron Microscopic Examination. Surgical Neurology, 27, 338-342. https://doi.org/10.1016/0090-3019(87)90008-5

[228] Wozniak, M., Mclone, D.G. and Raimondi, A.J. (1975) Micro- and Macro-Vascular Changes as the Direct Cause of Parenchymal Destruction in Congenital Murine Hydrocephalus. Journal of Neurosurgery, 43, 535-545. https://doi.org/10.3171/jns.1975.43.5.0535

[229] Glees, P., Hasan, M., Voth, D. and Schwarz, M. (1989) Fine Structural Features of the Cerebral Microvasculature in Hydrocephalic Human Infants: Correlated Clinical Observations. Neurosurgical Review, 12, 315-321.

https://doi.org/10.1007/BF01780849

[230] Hasan, M. and Glees, P. (1990) The Fine Structure of Human Cerebral Perivascular Pericytes and Juxtavascular Phagocytes: Their Possible Role in Hydrocephalic Edema Resolution. Journal Fur Hirnforschung, 31, 237-249.

[231] Castejon, O.J. (1980) Electron Microscopic Study of Capillary Wall in Human Cerebral Edema. Journal of Neuropathology \& Experimental Neurology, 49, 296-328. https://doi.org/10.1097/00005072-198005000-00006

[232] Shoesmith, C.L., Buist, R. and Del Bigio, M.R. (2000) Magnetic Resonance Imaging Study of Extracellular Fluid Tracer Movement in Brains of Immature Rats with Hydrocephalus. Neurological Research, 22, 111-116. 
https://doi.org/10.1080/01616412.2000.11741045

[233] Sykova, E., Fiala, J., Antonova, T. and Vorisek, I. (2001) Extracellular Space Volume Changes and Diffusion Barriers in Rats with Kaolin-Induced and Inherited Hydrocephalus. European Journal of Pediatric Surgery, 11, S34-S37.

[234] Bering, E.A.J. (1952) Water Exchange of Central Nervous System and Cerebrospinal Fluid. Journal of Neurosurgery, 9, 275-287. https://doi.org/10.3171/jns.1952.9.3.0275

[235] Go, K.G. (1997) The Normal and Pathological Physiology of Brain Water. Advances and Technical Standards in Neurosurgery, 23, 47-142. https://doi.org/10.1007/978-3-7091-6549-2_2

[236] Silva, A.C., Williams, D.S. and Koretsky, A.P. (1997) Evidence for the Exchange of Arterial Spin-Labeled Water with Tissue Water in Rat Brain from Diffusion-Sensitized Measurements of Perfusion. Magnetic Resonance in Medicine, 38, 232-237. https://doi.org/10.1002/mrm.1910380211

[237] Seyfert, S., Becher, A., Ohring, R. and Faulstich, A. (2004) The Permeability of the Blood-CSF Barrier in Hydrocephalus, Polyradiculitis, and Meningitis. Journal of Neurology, 251, 355-356. https://doi.org/10.1007/s00415-004-0334-2

[238] Mao, X., Enno, T.L. and Del Bigio, M.R. (2006) Aquaporin 4 Changes in Rat Brain with Severe Hydrocephalus. European Journal of Neuroscience, 23, 2929-2936. https://doi.org/10.1111/j.1460-9568.2006.04829.x

[239] Del Bigio, M.R., Slobodian, I., Schellenberg, A.E., Buist, R.J. and Kemp-Buors, T.L. (2011) Magnetic Resonance Imaging Indicators of Blood-Brain Barrier and Brain Water Changes in Young Rats with Kaolin-Induced Hydrocephalus. Fluids and Barriers of the CNS, 8, 22. https://doi.org/10.1186/2045-8118-8-22

[240] Strazielle, N. and Ghersi-Egea, J.F. (2000) Choroid Plexus in the Central Nervous System: Biology and Physiopathology. Journal of Neuropathology \& Experimental Neurology, 59, 561-574. https://doi.org/10.1093/jnen/59.7.561

[241] Toporek, C. and Robinson, K. (1999) Hydrocephalus: A Guide for Patients, Families, \& Friends. O’Reilly Media/Patient Centered Guides, Sebastopol.

[242] Hochwald, G.M., Sahar, A., Sadik, A.R. and Ransohoff, J. (1969) Cerebrospinal Fluid Production and Histological Observations in Animals with Experimental Obstructive Hydrocephalus. Experimental Neurology, 25, 190-199. https://doi.org/10.1016/0014-4886(69)90043-0

[243] Dohrmann, G.J. (1971) The Choroid Plexus in Experimental Hydrocephalus. A Light and Electron Microscopic Study in Normal, Hydrocephalic, and Shunted Hydrocephalic Dogs. Journal of Neurosurgery, 34, 56-69. https://doi.org/10.3171/jns.1971.34.1.0056

[244] Lawson, R.F. and Raimondi, A.J. (1973) Hydrocephalus-3, a Murine Mutant: I. Alterations in Fine Structure of Choroid Plexus and Ependyma. Surgical Neurology, 1, 115-128.

[245] Liszczak, T.M., Black, P.M., Tzouras, A., Foley, L. and Zervas, N.T. (1984) Morphological Changes of the Basilar Artery, Ventricles, and Choroid Plexus after Experimental SAH. Journal of Neurosurgery, 61, 486-493. https://doi.org/10.3171/jns.1984.61.3.0486

[246] Preston, J.E., McMillan, P.N., Stopa, E.G., Nashold, J.R., Duncan, J.A. and Johanson, C.E. (2003) Atrial Natriuretic Peptide Induction of Dark Epithelial Cells in Choroid Plexus: Consistency with the Model of CSF Downregulation in Hydrocephalus. European Journal of Pediatric Surgery, 13, S40-S42. 
[247] Madhavi, C. and Jacob, M. (1990) Morphometry of Choroid Plexus in Hydrocephalic Guinea Pigs. Indian Journal of Medical Research, 92, 89-94.

[248] Madhavi, C. and Jacob, M. (1992) Morphometry of Mitochondria in the Choroidal Ependyma of Hydrocephalic Guinea Pigs. Indian Journal of Medical Research, 96, 72-77.

[249] Shuman, C.S. and Bryan, J.H.D. (1991) Comparative Quantitative Ultrastructural Studies of the Choroidal Epithelium of Hydrocephalic (hpy/hpy) and Normal Mice, and the Effect of Stress Induced by Water Deprivation. Anatomischer Anzeiger, $173,33-44$.

[250] Silverberg, G.D., Huhn, S., Jaffe, R.A., Chang, S.D., Saul, T., Heit, G., Von Essen, A. and Rubenstein, E. (2002) Downregulation of Cerebrospinal Fluid Production in Patients with Chronic Hydrocephalus. Journal of Neurosurgery, 97, 1271-1275.

https://doi.org/10.3171/jns.2002.97.6.1271

[251] Acikgoz, B., Akpinar, G., Bingol, N. and Usseli, I. (1999) Angiotensin II Receptor Content within the Circumventricular Organs Increases after Experimental Hydrocephalus in Rats. Acta Neurochirurgica, 141, 1095-1099.

https://doi.org/10.1007/s007010050489

[252] Irigoin, C., Rodriguez, E.M., Heinrichs, M., Frese, K., Herzog, S., Oksche, A. and Rott, R. (1990) Immunocytochemical Study of the Subcommissural Organ of Rats with Induced Postnatal Hydrocephalus. Experimental Brain Research, 82, 384-392. https://doi.org/10.1007/BF00231257

[253] Somera, K.C. and Jones, H.C. (2004) Reduced Subcommissural Organ Glycoprotein Immunoreactivity Precedes Aqueduct Closure and Ventricular Dilatation in $\mathrm{H}-\mathrm{Tx}$ Rat Hydrocephalus. Cell and Tissue Research, 315, 361-373. https://doi.org/10.1007/s00441-003-0843-9

[254] Spoerri, O. and Alexy, H.J. (1974) The Subfornical Organ in Murine Hydrocephalus: A Light Microscopic Study. Developmental Medicine \& Child Neurology, 16, 91-94. https://doi.org/10.1111/j.1469-8749.1974.tb03455.x

[255] Del Bigio, M.R., Khan, O.H., da Silva Lopes, L. and Packiasamy, A.R.J. (2012) Cerebral White Matter Oxidation and Nitrosylation in Young Rodents with Kaolin-Induced Hydrocephalus. Journal of Neuropathology \& Experimental Neurology, 71, 274-288. https://doi.org/10.1097/NEN.0b013e31824c1b44

[256] Arteel, G.E., Thurman, R.G. and Raleigh, J.A. (1998) Reductive Metabolism of the Hypoxia Marker Pimonidazole Is Regulated by Oxygen Tension Independent of the Pyridine Nucleotide Redox State. European Journal of Biochemistry, 253, 743-750. https://doi.org/10.1046/j.1432-1327.1998.2530743.x

[257] Caner, H., Atasever, A., Kilinç, K., Durgun, B., Peker, S. and Ozcan, O.E. (1993) Lipid Peroxide Level Increase in Experimental Hydrocephalus. Acta Neurochirurgica (Wien), 121, 68-71. https://doi.org/10.1007/BF01405185

[258] Etus, V., Gazioglu, N. and Belce, A. (2001) N-Acetylcystein Reduces Cerebral Lipid Peroxidation in a Rat Model of Infantile Hydrocephalus. Journal of Neurological Sciences (Turkish), 18, \#2.

[259] Etus, V., Altug, T., Belce, A. and Ceylan, S. (2003) Green Tea Polyphenol (-)-Epigallocatechin Gallate Prevents Oxidative Damage on Periventricular White Matter of Infantile Rats with Hydrocephalus. The Tohoku Journal of Experimental Medicine, 200, 203-209. https://doi.org/10.1620/tjem.200.203

[260] Mori, K., Miyake, H., Kurisaka, M. and Sakamoto, T. (1993) Immunohistochemical Localization of Superoxide Dismutase in Congenital Hydrocephalic Rat Brain. Child s Nervous System, 9, 136-141. 
[261] Krueger, R.C. (2004) Use of a Novel Double-Sandwich Enzyme-Linked Immunosorbent Assay Method for Assaying Chondroitin Sulfate Proteoglycans That Bear 3-Nitrotyrosine Core Protein Modifications, a Previously Unrecognized Proteoglycan Modification in Hydrocephalus. Analytical Biochemistry, 325, 52-61. https://doi.org/10.1016/j.ab.2003.10.004

[262] Stiles J. and Jernigan, T.L. (2010) The Basics of Brain Development. Neuropsychology Review, 20, 327-348. https://doi.org/10.1007/s11065-010-9148-4

\section{Abbrevations}

$\begin{array}{ll}\text { BBB } & \text { blood-brain-barrier } \\ \text { CSF } & \text { cerebrospinal fluid } \\ \text { GAP-43 } & \text { growth-associated protein-43 } \\ \text { GE } & \text { germinal eminence } \\ \text { H-Tx } & \text { hydrocephalus Texas } \\ \text { NOS } & \text { nitric oxide synthase } \\ \text { NPCs } & \text { neuronal progenitors cells } \\ \text { NSCs } & \text { neural stem cells } \\ \text { OPCs } & \text { oligodendrocyte precursors cells } \\ \text { SEZ } & \text { subependymal zone } \\ \text { SVZ } & \text { subventricular zone } \\ \text { VZ } & \text { ventricular zone }\end{array}$

